\title{
Late Holocene tephrostratigraphy from Cajas National Park, southern Ecuador
}

\author{
*Stéphanie H. Arcusa1, Tobias Schneider ${ }^{2,3}$, Pablo V. Mosquera ${ }^{4,5}$, Hendrik Vogel ${ }^{6}$, \\ Darrell Kaufman', Sönke Szidat ${ }^{7}$, Martin Grosjean ${ }^{3}$
}

\author{
1 School of Earth and Sustainability, Northern Arizona University, PO Box 4099, Flagstaff, AZ 86011-4099, USA. \\ sha59@nau.edu; darrell.kaufman@nau.edu \\ 2 Department of Geosciences, Morrill Science Center, University of Massachusetts, 611 North Pleasant Street, Amherst, MA 01003, USA. \\ tobias.schneider@giub.unibe.ch \\ 3 Institute of Geography and Oeschger Centre for Climate Change Research, University of Bern, Hallerstrasse 12, 3012 Bern, Switzerland. \\ martin.grosjean@oescher.unibe.ch \\ 4 Subgerencia de Gestión Ambiental, Empresa Pública Municipal de Telecomunicaciones, Agua potable, Alcantarillado y Saneamiento \\ (ETAPA EP), Benigno Malo 7-78, Cuenca EC010101, Ecuador. \\ pmosquerav@gmail.com \\ 5 Departament de Biologia Evolutiva, Ecologia i Ciències Ambientals, Universitat de Barcelona, Diagonal 643, 08028 Barcelona, Spain. \\ ${ }^{6}$ Institute of Geological Sciences and Oeschger Center for Climate Change Research, University of Bern, Baltzerstrasse 3, 3012 Bern, \\ Switzerland. \\ hendrik.vogel@geo.unibe.ch \\ 7 Department of Chemistry and Biochemistry and Oeschger Centre for Climate Change Research, University of Bern, Baltzerstrasse 3, \\ 3012 Bern, Switzerland. \\ szidat@dcb.unibe.ch
}

*Corresponding author: sha59@nau.edu

\begin{abstract}
Lakes located downwind of active volcanoes serve as a natural repository for volcanic ash (tephra) produced during eruptive events. In this study, sediment cores from four lakes in Cajas National Park, southern Ecuador, situated approximately $200 \mathrm{~km}$ downwind of active volcanoes in the Northern Andes Volcanic Zone, were analysed to document the regional history of tephra fall extending back around 3,000 a cal BP. The ages of the lacustrine sedimentary sequences were constrained using a total of 20 AMS radiocarbon ages on plant remains. The tephra layers were correlated among the lakes based on their radiocarbon age, elemental composition, colour, and grain morphology. We found five unique tephra layers, each at least $0.2 \mathrm{~cm}$ thick, and further constrained their ages by combining the results from two age-depth modelling approaches (clam and rbacon). The tephra layers were deposited 3,034 $\pm 621,2,027 \pm 41$, $1,557 \pm 177,733 \pm 112$, and $450 \pm 70$ a cal BP. The ages of all but the youngest tephra layer overlap with those of known eruptions from Tungurahua. Some tephra layers are missing as macroscopic layers in several cores, with only two of the five tephra layers visible in the sediment of three lakes. Likewise, previous studies of lake sediment cores from the region are missing the four youngest tephra layers, further highlighting the need to sample multiple lakes to reconstruct a comprehensive history of fallout events. The newly documented stratigraphic marker layers will benefit future studies of lake sediments in Cajas National Park.
\end{abstract}

Keywords: Tephra, Taphonomy, Tephra morphology, Radiocarbon, ${ }^{14}$ C chronology, Limnogeology, Andes, South America. 
RESUMEN. Tefroestratigrafía del Holoceno Tardío, Parque Nacional Cajas, Ecuador. Lagos que están localizados en la trayectoria del viento que proviene desde volcanes activos, sirven como repositorios naturales de cenizas volcánicas (tefra) producidas durante eventos eruptivos. En este estudio, se analizaron testigos de sedimentos obtenidos en sondajes realizados en cuatro lagos del Parque Nacional Cajas, en el sur de Ecuador, situados aproximadamente a $200 \mathrm{~km}$ de volcanes activos en la Zona Volcánica Norte de los Andes. El objetivo del estudio es documentar la historia regional de la depositación de tefras ocurrida en los últimos 3.000 años. Las edades de las secuencias sedimentarias lacustres fueron definidas con un total de 20 edades de radiocarbono AMS realizadas en restos de plantas fosilizados. Los niveles de tefras fueron correlacionados entre los lagos sobre la base de su edad de radiocarbono, color y morfología de grano. Se identificaron cinco niveles de tefras, cada uno de al menos $0,2 \mathrm{~cm}$ de espesor, y sus edades fueron adicionalmente restringidas con los resultados provenientes de dos modelos de edad-profundidad (clam y rbacon) aplicados a las secuencias sedimentarias. Las tefras fueron depositadas a $3.034 \pm 621,2.027 \pm 41,1.557 \pm 177,733 \pm 112, \mathrm{y} 450 \pm 70$ a cal AP. Las edades de todas, menos la de la capa de tefra más joven, se superponen con las de erupciones conocidas del volcán Tungurahua. En varios de los testigos de sedimentos los niveles de tefras no son visibles como capas macroscópicas, solamente dos de los cinco niveles de tefra identificados eran observables en la secuencia sedimentaria de tres de los lagos. Estudios previos de testigos de sedimento lacustre realizados en la región no registraron la presencia de los cuatro niveles de tefras más jóvenes, lo que realza la necesidad de muestrear múltiples lagos para reconstruir una historia completa de eventos de depositación de ceniza volcánica originada por eventos eruptivos. Las capas de tefras recién documentadas consituyen marcadores estratigráficos que beneficiarán futuros estudios de sedimentos lacustres en el Parque Nacional Cajas.

Palabras clave: Tefra, Tafonomía, Morfología de tefra, Radiocarbono, Cronología ${ }^{14}$ C, Limnogeología, Andes, América del Sur.

\section{Introduction}

Tephrochronology is increasingly useful in Quaternary paleoenvironmental research. Tephra beds record explosive volcanic eruptions extending back beyond direct observations in a region. This is fundamental for risk assessments based on eruption frequencies and magnitudes as inferred from long (e.g., Holocene) tephrochronological time series (Alloway et al., 2013). Furthermore, tephra layers serve as chronostratigraphic markers that are deposited simultaneously over extensive areas and in a variety of terrestrial and aquatic settings. Such markers are useful to evaluate and improve chronologies of sedimentary successions, including those recovered from lakes (Lowe, 2011).

Developing tephrochronologies from lakes using sedimentary records can be challenging. Different methods of tephra analysis including geochemistry, colour, grain morphology, and stratigraphy can yield conflicting results (Shane, 2000; Zawalna-geer et al., 2016). Additionally, multiple variables influence the completeness of a tephra fall sequence at a site. For example, wind direction, secondary deposition, reworking, dissolution, and narrow plumes can generate variable tephra stratigraphic records (e.g., Boygle, 1999; De Fontaine et al., 2007). To address the issue of heterogeneous areal deposition a multi-lake approach with multiple sediment cores is needed for a comprehensive account of tephra fall events.
Of the 20 active volcanoes in Ecuador (Hall et al., 2008), many have experienced disruptive to devastating historical eruptions (Fig. 1A; Venzke, 2016) but less is known about pre-historic eruptions. Holocene tephrochronologies have been developed from several sites in Ecuador (e.g., Garrison et al., 2011; Hall et al., 1999; Hidalgo et al., 2008; Le Pennec et al., 2012; Monzier et al., 1999; Mothes and Hall, 2008) although only one from the southern part of the country (Rodbell et al., 2002) and none focusing on the past several thousand years (late Holocene).

Hundreds of lakes in Cajas National Park (CNP) occur on the eastern slope of the western Cordillera of south-central Ecuador (Mosquera et $a l ., 2017)$. They likely received tephra fall from explosive volcanism throughout the Quaternary making CNP an attractive location from which to produce a tephrostratigraphy. Although the prevailing winds are easterly and volcanoes are located north of the park, the park is close to several active volcanoes (Fig. 1A). Previous work in the park revealed seven Holocene tephra deposits, yet none during the last 2,000 years (Rodbell et $a l ., 2002,2008)$. This is unexpected because at least 34 late Holocene eruptions with Volcanic Eruption Index $(\mathrm{VEI}) \geq 4$ have occurred in Ecuador, some from volcanoes like Tungurahua, which is located within $200 \mathrm{~km}$ to the north of the park (Venzke, 2016). 

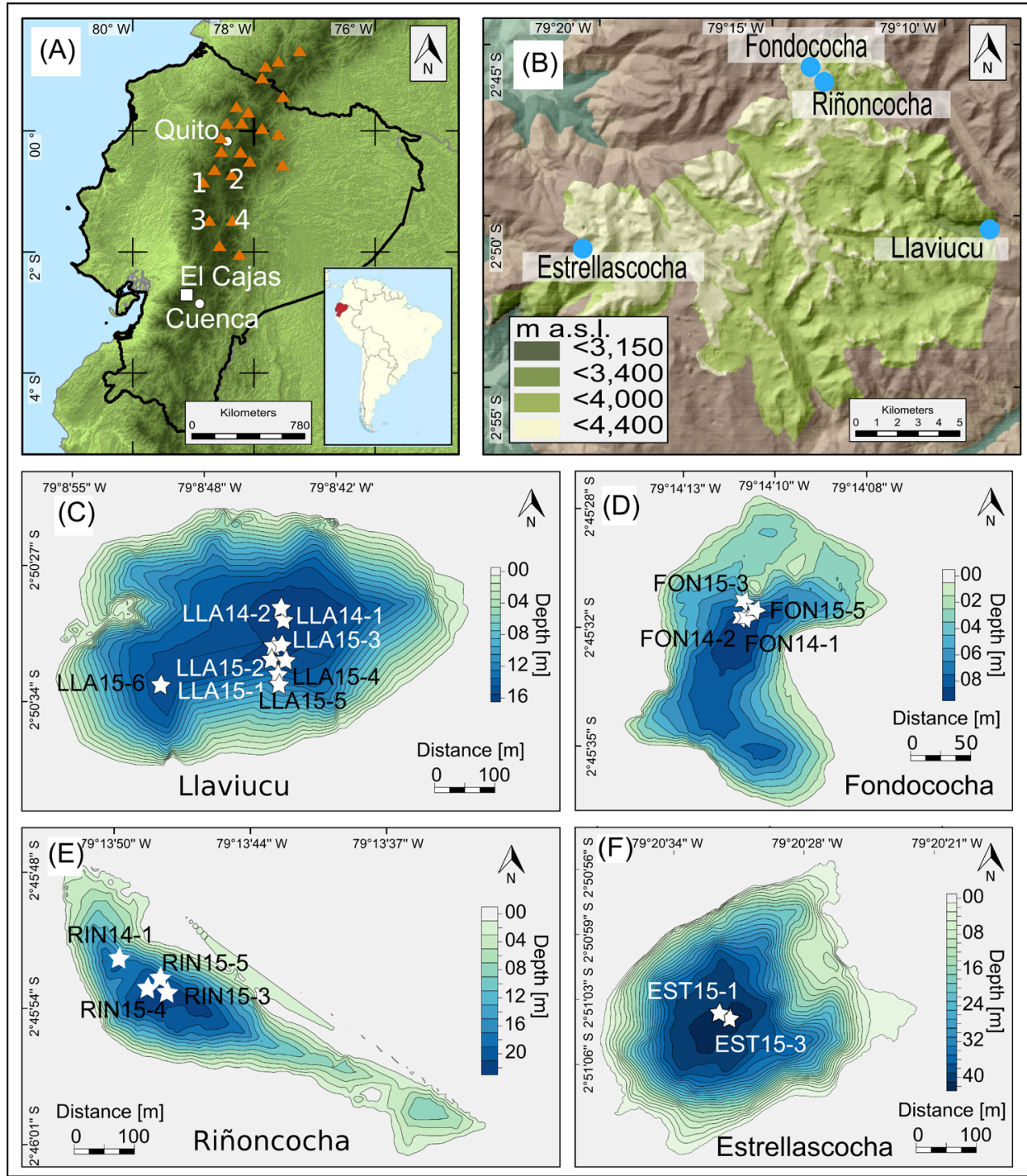

FIG. 1. Study site. A. Ecuador showing El Cajas National Park, southern Ecuador, in relation to active volcanoes (triangles) (Venzke, 2016). Volcano 1: Quilotoa, 2: Cotopaxi, 3: Chimborazo, and 4: Tungurahua. Inset in (A) shows the location of Ecuador in South America. B. El Cajas National Park (green area) showing the locations of Lakes Llaviucu, Fondococha, Riñoncocha, and Estrellascocha (blue dots) and the elevation gradient. Bathymetry maps for Lakes Llaviucu (C), Fondococha (D), Riñoncocha (E), and Estrellascocha (F), showing the coring locations (asterisks).

In this study, we develop a tephrostratigraphy of the last 3,000 years using a multi-lake, multi-core approach in CNP, southern Ecuador. Radiocarbon dating, with supporting evidence from tephra colour, and grain morphology are used to distinguish and date five regionally distributed late Holocene marker layers. This study also points to challenges using lake sediments to establish tephrostratigraphy in this type of environment.

\section{Study Area and Previous Work}

Cajas National Park (CNP, S 79¹0' W, Fig. 1A, B) is located in southern Ecuador and ranges from $3,150 \mathrm{~m}$ to $4,400 \mathrm{~m}$ a.s.l. Bedrock consists mainly of andesite, rhyolite, and tuff of the Pleistocene Tarqui Formation (Paladines and Guzmán, 1980). The landscape is covered with Holocene Andosols and Histosols (Buytaert et al., 2006; Harden, 2006) 
and hosts 218 lakes of glacial origins (Van Colen et $a l ., 2017$ ) and over 5,000 water bodies (Mosquera et al., 2017).

Because heterogeneous areal distribution of tephra deposition affects all lakes, sampling of lakes in a variety of settings allows us to define a more complete tephrostratigraphy for the area. We selected four lakes located closely $(<20 \mathrm{~km})$ one to another, but in different settings (Table 1). Lakes Llaviucu, Fondococha, Riñoncocha, and Estrellascocha are four exorheic high-altitude lakes in CNP (Fig. 1B-F) arranged E-W along an elevation gradient of ca. $1,000 \mathrm{~m}$. Their catchment characteristics differ in slope steepness, vegetation type, and catchmentto-lake area ratio (Table 1).

Previous research on tephrochronology using lake sediments in CNP is limited to one published study. Rodbell et al. (2002) developed the first tephrochronology for this area based on Lake Llaviucu and five other lakes, and they identified seven late-glacial and Holocene tephra layers (A-G, Rodbell et al., 2002). The youngest of these tephra layers dates to $c a$. 4,100 a cal BP in Lake Llaviucu, which is geochemically correlated to the uppermost tephra layer in Lake Chorreras (dated to $c a \cdot 3,400$ a cal BP) and to the uppermost tephra layer in Lake Pallcacocha (F, G dated to 3,380 and 4,430 a cal BP, respectively). Thus, the age of the youngest tephra layer identified up to now is relatively poorly constrained (Rodbell et al., 2002), and these authors also noted the absence of tephra layers for the past two millennia. For their study on late Holocene clastic event layers, Schneider et al. (2018) established a first radiocarbon $\left({ }^{14} \mathrm{C}\right)$ chronology for Lake Fondococha and found that ${ }^{14} \mathrm{C}$ dating of these lake sediments is challenging because sediment organic matter is strongly decomposed, terrestrial macrofossils are scarce, and bulk sediment organic matter is affected by ${ }^{14} \mathrm{C}$ reservoir effects.

\section{Methods}

\subsection{Coring, sediment description and non- destructive methods}

Sediment cores were retrieved from the four lakes in 2014 and 2015 (core ID names identified as 14 and 15 , respectively) using a gravity coring system with percussion hammer $(6 \mathrm{~cm}$ diameter, UWITEC, Austria) operated from a rubber raft. Between two and six cores, each between 50 - and $195 \mathrm{~cm}$ long were obtained from or near the depocenter of the lakes (Fig. 1C-F). The sediment surfaces were preserved using wet floral foam. The sediment cores were shipped to the University of Bern, Switzerland and stored in the dark at $4{ }^{\circ} \mathrm{C}$ until analysis. The sealed whole cores were first scanned for magnetic susceptibility (MS) and gamma-ray-inferred density with a MultiSensor Core Logger (MSCL, Geotek; Schultheiss and Weaver, 1992) at $1 \mathrm{~cm}$ resolution. The cores were then split, and the sediment was described after Schnurrenberger et al. (2003). Colour was identified

TABLE 1. LAKE AND CATCHMENT CHARACTERISTICS FOR LAKES LLAVIUCU, FONDOCOCHA, RIÑONCOCHA, AND ESTRELLASCOCHA.

\begin{tabular}{|c|c|c|c|c|}
\hline Parameters & Llaviucu & Fondococha & Riñoncocha & Estrellascocha \\
\hline Lat. (S) & $2^{\circ} 50^{\prime} 35.5194^{\prime \prime}$ & $2^{\circ} 45^{\prime} 35.2794^{\prime \prime}$ & $2^{\circ} 45^{\prime} 59.0394^{\prime \prime}$ & $2^{\circ} 51^{\prime} 7.9194 ”$ \\
\hline Lon. (W) & $79^{\circ} 8{ }^{\prime} 45.96 "$ & $79^{\circ} 14^{\prime} 11.04^{\prime \prime}$ & $79^{\circ} 13^{\prime} 46.9194 "$ & $79^{\circ} 20^{\prime} 31.56^{\prime \prime}$ \\
\hline Elev. (m a.s.1.) & 3,152 & 4,127 & 4,034 & 4,128 \\
\hline Max. depth (m) & 16.5 & 9.9 & 29.6 & 41.6 \\
\hline $\mathrm{LA}\left(\mathrm{km}^{2}\right)$ & 0.19 & 0.03 & 0.1 & 0.12 \\
\hline $\mathrm{CA}\left(\mathrm{km}^{2}\right)$ & 47.70 & 0.6 & 3.87 & 1.46 \\
\hline $\mathrm{CA} / \mathrm{LA}$ & 253 & 18 & 6 & 12 \\
\hline $\begin{array}{l}\text { Vegetation } \\
\text { community }\end{array}$ & $\begin{array}{c}\text { Pasture grassland } / \text { montane, } \\
\text { Andean forest }\end{array}$ & Paramo/sub-paramo & Paramo/sub-paramo & Paramo/sub-paramo \\
\hline Trophic state & Mesotrophic & Oligotrophic & Oligotrophic & Oligotrophic \\
\hline
\end{tabular}

Lat: latitude; Lon: longitude; Elev: elevation; LA: lake area; CA: catchment area. Information from Mosquera et al. (2017). 
following Munsell's colour chart. A micro X-Ray Fluorescence ( $\mu$ XRF) scanner (ITRAX $\odot$, Cox Analytical System) was used to measure the elemental composition (Croudace et al., 2006) at a resolution of $2 \mathrm{~mm}$ for the 2014 half cores and $1 \mathrm{~mm}$ increments for the 2015 half cores to detect tephra layers and cryptotephra-bearing horizons (Vogel et al., 2010). The 2014 split cores were measured using a Mo tube $(40 \mathrm{kV}, 20 \mathrm{~mA})$ with $10 \mathrm{~s}$ exposure time to detect Al, Si, K, Ca, Ti, Mn, Fe, Rb, S, Sr, and Zr. The 2015 split cores were measured with higher voltage $(45 \mathrm{kV})$ and longer exposure $(20 \mathrm{~s})$ to detect additional elements $(\mathrm{Ni}, \mathrm{Cu}, \mathrm{Pb}, \mathrm{Br})$. The split cores were additionally imaged using X-Ray Radiography (RAD, $0.2 \mathrm{~mm}$ resolution) to detect differences in the sediment density at high resolution. Core-face photographs (visible and near infrared) were acquired using a SPECIM Ltd. VNIR hyperspectral imaging scanning system (Butz et al., 2015). In cores from Lake Fondococha, clastic event layers related to high runoff were previously determined by Schneider et al. (2018) using Principal Component Analysis (PCA) of elemental compositions and visual inspection. Organic-rich debris and clastic layers were mapped visually in Lake Llaviucu and interpreted as rapidly deposited event deposits.

\subsection{Tephra layer identification}

This study focuses on the visually prominent, relatively pure tephra beds and some cryptotephra, disseminated tephra shards that are not macroscopically obvious. Samples from tephra layers that could be easily correlated among cores from the same lake were combined to increase the mass of relatively pure tephra sample. Tephra layers were distinguished from the ambient lacustrine sediment by their brighter colour, higher MS, higher $\mathrm{Sr}$ and $\mathrm{Si}$ abundances (Vogel et al., 2010), low RAD, and presence of relatively angular glass shards as visualised through light microscopy and Scanning Electron Microscopy (SEM). Zones of higher $\mathrm{Sr}$ and $\mathrm{Si}$ abundances were investigated for cryptotephra using smear slides. The size and shape of tephra grains were analysed from SEM images using the modified method of Liu et al. (2016). Grain-size was not used to assess componentry. Additionally, elemental composition for each macro tephra layer was obtained from $\mu$ XRF (e.g., Vogel et al., 2010; Kylander et al., 2012; Peti et al., 2019). PCA was used to aid correlation among tephra beds by visualising the distribution of the samples' elemental composition in a lowdimensional space.

\subsection{Tephra layer age determination}

Lake sediments were sampled contiguously and wet sieved ( $120 \mu \mathrm{m}$ mesh, $0.5-1.0 \mathrm{~cm}$ intervals) to recover terrestrial plant remains. As identifiable terrestrial plant remains were scarce, we also performed parallel ${ }^{14} \mathrm{C}$ AMS measurements on the bulk sediment to assess whether these materials yield reliable ${ }^{14} \mathrm{C}$ ages or are affected by ${ }^{14} \mathrm{C}$ reservoir effects (Geyh et al., 1999). Plant remains were identified and taxonomically classified under dissecting microscope and dated with a ${ }^{14}$ C AMS MIni-CArbon DAting System (MICADAS) at the University of Bern (Szidat et al., 2014). The smallest samples $(<100 \mu \mathrm{g}$ carbon) were analysed with direct gas injection (Salazar et al., 2015); larger samples were analysed following conversion to graphite. All ${ }^{14} \mathrm{C}$ ages were calibrated to calendar years using the IntCal13 northern hemisphere calibration (Reimer et al., 2013) because CNP is located within the South American Summer Monsoon region and thus is strongly influenced by the northern hemisphere air masses (Marsh et al., 2018).

The age-depth model for Lake Llaviucu was constrained by 12 new AMS ${ }^{14} \mathrm{C}$ ages on plant remains from two parallel cores mapped onto a composite (supplementary Fig. S1) and is presented here for the first time. The ${ }^{210} \mathrm{~Pb}$ activity profiles from the near-surface sediment of Lakes Fondococha and Llaviucu were previously presented in Bandowe et al. (2018). The age-depth model for Lake Fondococha was initially developed by Schneider et al. (2018) and is complemented here with additional ${ }^{14} \mathrm{C}$ dates to better constrain the ages of the tephra layers.

These age-depth models were used to date the tephra layers in cores from Lakes Llaviucu and Fondococha. Due to the lack of suitable material, ${ }^{14} \mathrm{C}$ chronologies could not be established for Lakes Riñoncocha and Estrellascocha. In these lakes, no identifiable terrestrial plant remains could be found, despite extensive sediment sieving ( $63 \mu \mathrm{m}$ mesh). The age assigned to each tephra bed in this study was based on the two lakes with age-depth models. In addition, we compared the results of two commonly applied age-depth modelling routines, namely clam v.2.3.2 (Blaauw, 2019) and rbacon v.2.3.9.1 (Blaauw and Christen, 2019), both available for the open- 
source statistical software "R" (R Core Team, 2019) (supplementary Table S1). Each model for each lake yielded tephra layer ages and uncertainty, for a total of four age estimates per tephra layer (two lakes and two models per lake). The best age estimates for each tephra layer were calculated as the mean age at the base of the tephra layer bed as represented by the four age estimates, with each age weighted by the inverse of the one-sigma range of the uncertainty (supplementary Table S2). The age uncertainty was calculated as the root mean squared error (RMSE) based on the uncertainties of the four age estimates. Pure tephra beds and clastic-rich layers interpreted as flood deposits (identified based on datasets described below) were considered instantaneous and therefore removed from the age-depth models (supplementary Table S3).

\section{Results}

\subsection{Sediment stratigraphy}

The sediment in Lake Llaviucu is composed of brownish black (HUE 10YR3/1) organic-rich silt with layers of plant remains interspersed with olive yellow (HUE 5Y6/4) to greyish olive (HUE 7.5YR6/2) laminae. Sediment from Lake Fondococha was previously described as brownish black (HUE 10YR2/1) organic-rich, laminated silty clay (Schneider et al., 2018; Fig. 2). Similarly, the sediment of Lake Riñoncocha consists of a pink (HUE 7.5YR8/3), thinly laminated clay section $(110-130 \mathrm{~cm}$ sediment depth) overlain by yellowish brown (HUE 10YR5/4) thinly laminated silty clay that progressively grades upward to brownish black (HUE 10YR2/1) massive sediment. The sediment consists of strongly decomposed organic matter, diatom ooze, and siliciclastic volcanic material. Unlike the other lakes, Lake Estrellascocha's sediment consists of brown (HUE 10YR5/3), massive silty clay derived from volcanic siliciclastic rocks, and comprises strongly decomposed organic matter and diatom ooze.

The prominent $\mathrm{mm}$ - to $\mathrm{cm}$-thick, normally graded, silty-clay beds found in cores from Lake Fondococha were previously interpreted as flooddeposited sediments (Schneider et al., 2018). In Lake Llaviucu, the layers are also normally graded, and their origin is interpreted similarly in this study.

Cores collected from nearby sites in 2014 and 2015 were readily correlated based on prominent tephra layers in Lakes Fondococha and Riñoncocha (supplementary Fig. S1), but three visible tephra layers were missing from some of the cores. The youngest tephra layer found in Lake Llaviucu is missing in LLA14-1, the oldest tephra layer found in Lake Fondococha is missing from FON15-5, and the two oldest tephra layers found in Lake Estrellascocha are missing in EST15-1. However, we did not explicitly search for cryptotephra at the depths where they should have been located. Correlation using MS and $\mu \mathrm{XRF}$ data between multiple cores from Lake Llaviucu proved more challenging due to the abundance of clastic sediment layers but led to the conclusion that $22 \mathrm{~cm}$ of sediment was missing in core LLA15-6 (supplementary Fig. S1). A master sediment core composite for Lake Llaviucu was constructed from cores LLA14-1, LLA14-2, and LLA15-6.

\subsection{Age-depth models}

Twenty AMS ${ }^{14} \mathrm{C}$ ages distributed between Lakes Llaviucu and Fondococha were used to develop agedepth models (Table 2, Fig. 3). The 12 ages from Lake Llaviucu are published here for the first time and four ages are added to the four already published for Lake Fondococha (Schneider et al., 2018). An additional ten ages were rejected; four were on bulk sediment and insect chitin (BE-3530.1.1, BE-3527.1.1, BE3528.1.1, BE-3529.1.1). The bulk samples returned ages that are about 400-600 years older than indicated by the ages of terrestrial macrofossils measured in parallel samples, suggesting that the organic $\mathrm{C}$ had been stored on the landscape for centuries prior to entering the lake and thus the reservoir effect is not constant. Three of the rejected samples (BE-10953.1.1, BE-4779.1.1, BE-10956.1.1) were smaller than 0.1 mg dry mass and are therefore judged as unreliable. One returned a post-bomb spike age (BE-10954.1.1), one was from the near-surface where the ${ }^{210} \mathrm{~Pb}$ age profile was used instead (BE-3518.1.1), and one was an outlier as determined by falling beyond the $95 \%$ confidence interval of the age-depth model (BE4782.1.1). Age-depth models were also generated (not shown) using all the ages and the ages of the tephra layers were not substantially different, although the uncertainties were larger. Dating uncertainty was $< \pm 100$ years (1 standard deviation) for samples larger than $0.2 \mathrm{mg}$ dry mass but increased to $> \pm 200$ years (1 standard deviation) for samples with mass $<0.1 \mathrm{mg}$ dry mass. 
Lake Llaviucu (master core)

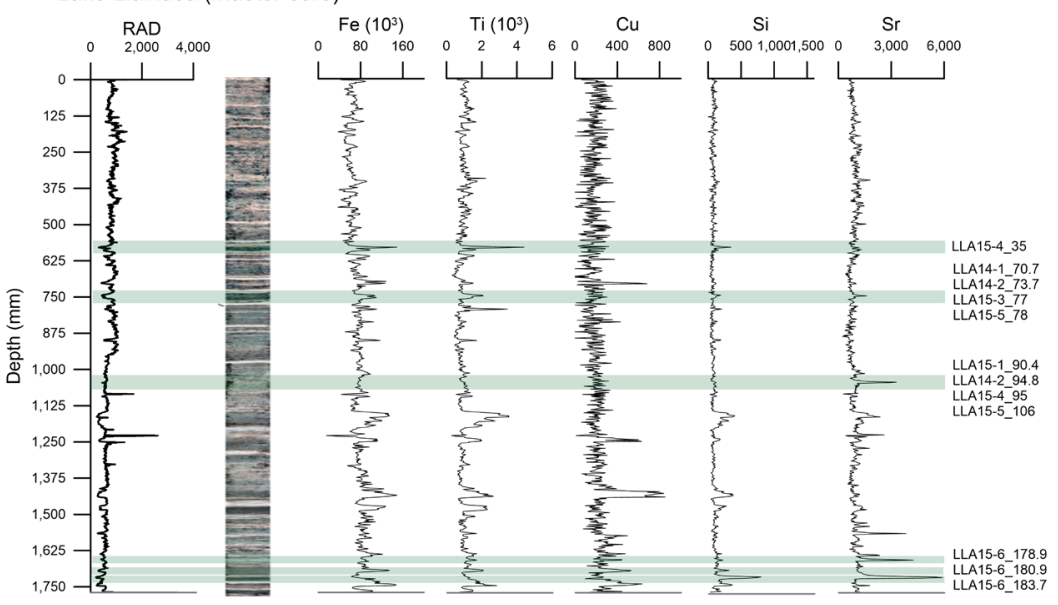

Lake Riñoncocha (RIN14-2-B)
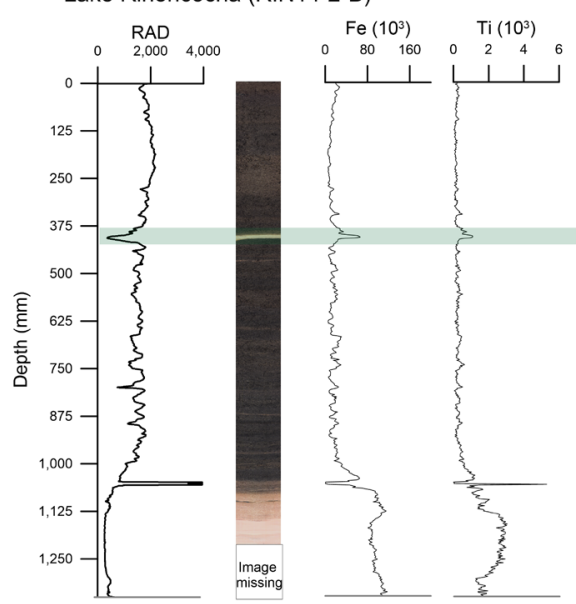

Lake Fondococha (FON14-1-A)

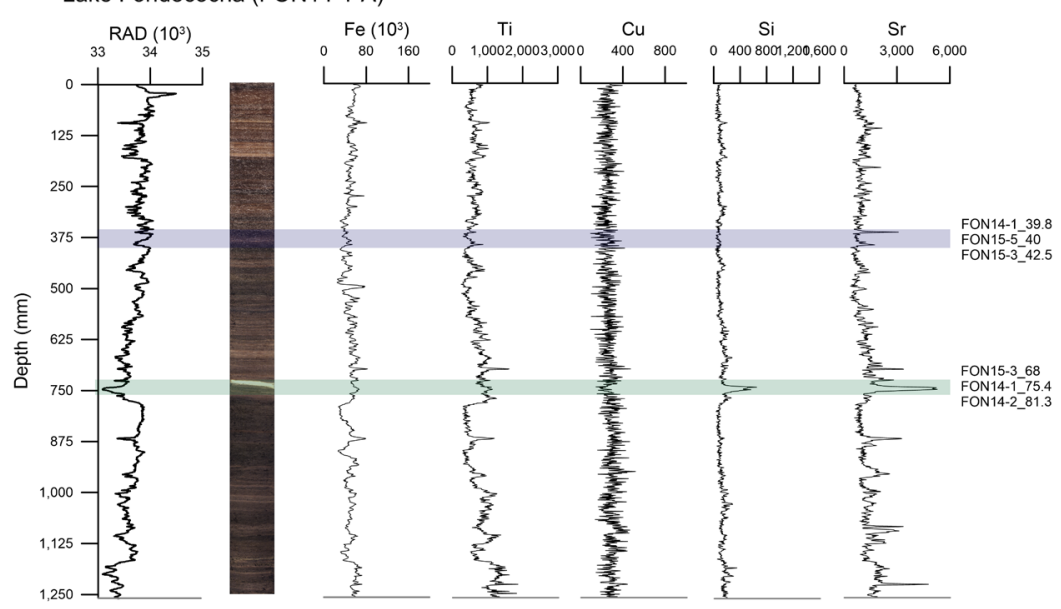

Lake Estrellascocha (EST15-3)

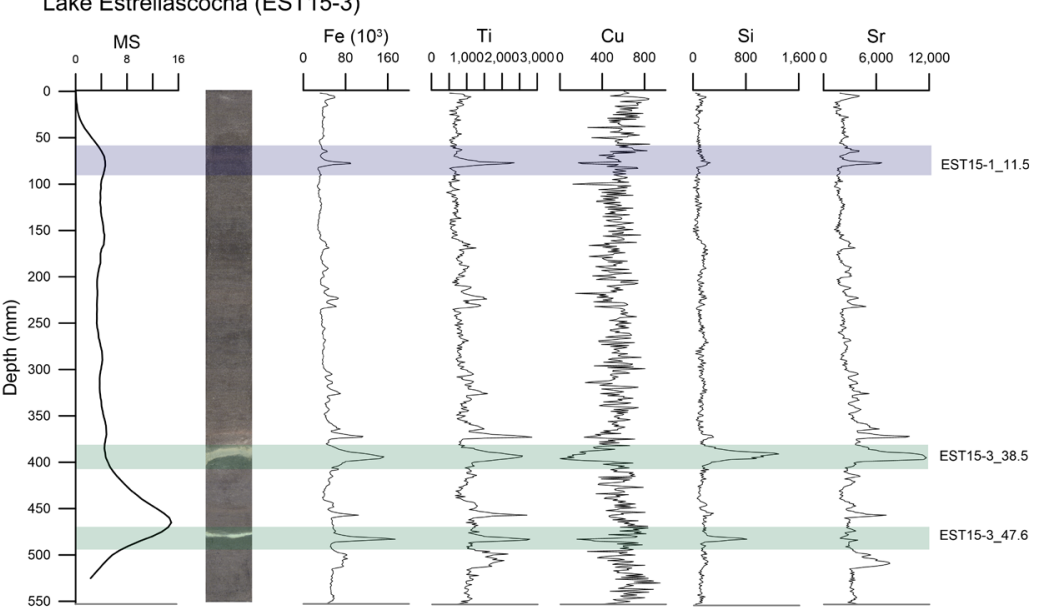

FIG. 2. Core images, MS (magnetic susceptibility), RAD (X-Radiography Density) and $\mu \mathrm{XRF}$ (micro X-Ray Fluorescence; Fe, Ti, Cu, $\mathrm{Si}$, and $\mathrm{Sr}$ ) counts presented for the four lake sediment cores. Investigated visible tephra and cryptotephra layers are highlighted in green and purple, respectively. Note the different vertical scales. LLA photo is colour-enhanced to increase contrast between background sediment and event layers. Tables containing XRF data can be found in supplementary Table S4. Also note that Lake Llaviucu layers identified in the figure are from three different cores whereas the core photo, RAD, and $\mu \mathrm{XRF}$ are from the composite core so have different depths. 
TABLE 2. SUMMARY OF ANALYSED SAMPLES AND ${ }^{14}$ C DATA.

\begin{tabular}{|c|c|c|c|c|c|c|c|c|}
\hline Core ID & LARA lab ID & $\begin{array}{l}\text { Mid-point } \\
\text { depth (cm) }\end{array}$ & Material & $\begin{array}{c}\text { Sample } \\
\text { mass (mg) }\end{array}$ & $\begin{array}{l}\text { AMS } \\
\text { source }\end{array}$ & ${ }^{14} \mathrm{C}$ a BP & $\begin{array}{c}\text { Uncertainty } \\
\quad( \pm \text { 1SD })\end{array}$ & $\begin{array}{l}\text { a cal BP } \\
\text { (median) }\end{array}$ \\
\hline LLA14-1-A* & BE-3518.1.1 & 21.15 & $\begin{array}{l}\text { Isolepsis and } \\
\text { Loricaria } \\
\text { fragments }\end{array}$ & 0.405 & gas & 157 & 78 & 163 \\
\hline LLA14-1-A* & BE-3527.1.1 & 21.15 & Bulk sediment & 678.5 & graphite & 682 & 34 & 650 \\
\hline LLA14-1-A & BE-3519.1.1 & 55.45 & $\begin{array}{l}\text { Loricaria leaf } \\
\text { fragments }\end{array}$ & 2.804 & graphite & 317 & 22 & 387 \\
\hline LLA14-1-A* & BE-3528.1.1 & 55.45 & Bulk sediment & 868.6 & graphite & 891 & 22 & 804 \\
\hline LLA15-6 & BE-4778.1.1 & 59.5 & $\begin{array}{l}\text { Wood and } \\
\text { Loricaria } \\
\text { fragments }\end{array}$ & 0.648 & graphite & 332 & 44 & 392 \\
\hline LLA15-3* & BE-4779.1.1 & 61.6 & Seed husk & 0.065 & gas & 2,378 & 235 & 2,438 \\
\hline LLA14-1* & BE-10954.1.1 & 70 & Unidentified & 0.117 & gas & -24 & 63 & 100 \\
\hline LLA15-3 & BE-4780.1.1 & 71.5 & $\begin{array}{l}\text { Loricaria leaf } \\
\text { fragment }\end{array}$ & 0.027 & gas & 1,274 & 171 & 1,184 \\
\hline LLA14-1* & BE-10956.1.1 & 90 & $\begin{array}{l}\text { Grass and twig } \\
\text { fragments }\end{array}$ & 0.094 & gas & 2,239 & 85 & 2,233 \\
\hline LLA14-1 & BE-10955.1.1 & 107.5 & $\begin{array}{l}\text { Bark and grass } \\
\text { fragments }\end{array}$ & 0.252 & gas & 1,781 & 68 & 1,704 \\
\hline LLA14-1-A* & BE-3529.1.1 & 108.5 & Bulk sediment & 891.5 & graphite & 2,248 & 23 & 2,227 \\
\hline LLA-15-6-II-A & BE-4781.1.1 & 180.5 & Seed fragments & 0.043 & gas & 2,923 & 356 & 3,109 \\
\hline FON14-2-I-B* & BE-3530.1.1 & 26.55 & Bulk sediment & 963 & graphite & 940 & 26 & 853 \\
\hline FON14-2-I-B & BE-3520.1.1 & 30 & $\begin{array}{l}\text { Seed; Carex } \\
\text { tricuspid }\end{array}$ & 0.195 & gas & 301 & 62 & 377 \\
\hline FON15-3 & BE-4783.1.1 & 39.3 & $\begin{array}{l}\text { Loricaria leaf } \\
\text { fragment }\end{array}$ & 1.217 & graphite & 726 & 38 & 675 \\
\hline FON14-2-I & BE-10950.1.1 & 42.5 & $\begin{array}{l}\text { Periderm and } \\
\text { grass fragment }\end{array}$ & 0.095 & gas & 989 & 67 & 890 \\
\hline FON14-2-I* & BE-10953.1.1 & 53.5 & $\begin{array}{l}\text { Charred twig } \\
\text { fragments }\end{array}$ & 0.049 & gas & 1,943 & 99 & 1,893 \\
\hline FON15-3* & BE-4782.1.1 & 64.7 & $\begin{array}{l}\text { Loricaria leaf } \\
\text { fragment }\end{array}$ & 0.619 & graphite & 1,080 & 51 & 996 \\
\hline FON14-2-I & BE-10952.1.1 & 75.5 & $\begin{array}{l}\text { Charred twig } \\
\text { fragments }\end{array}$ & 0.347 & graphite & 2,104 & 50 & 2,079 \\
\hline FON14-2-I & BE-10951.1.1 & 92 & Bark fragment & 1.356 & graphite & 2,540 & 41 & 2,620 \\
\hline
\end{tabular}

* Ages not included in the final chronologies.

The 185-cm-long sediment sequence from Lake Llaviucu extends back to $c a$. 3,000 a cal BP. Five of the 12 measured ${ }^{14} \mathrm{C}$ ages were included in the age-depth models (Table 2). Sedimentation rates averaged over the entire core including event layers averages 0.58 and $0.62 \mathrm{~mm} / \mathrm{yr}$ for the clam and rbacon age-depth models, respectively, with clam projecting an age of about 200 years older at the base of the core. Excluding the event layers results in average rates of 0.45 and $0.48 \mathrm{~mm} / \mathrm{yr}$ in clam and rbacon, respectively. Both models indicate higher sedimentation over the last $c a$. 500 years, with average rates of $c a .1 \mathrm{~mm} / \mathrm{yr}$ and peak values reaching $2.5 \mathrm{~mm} / \mathrm{yr}$ in the last century. Between 500 and $900 \mathrm{a}$ cal BP the rbacon model indicates lower sedimentation rates $(c a .0 .3 \mathrm{~mm} / \mathrm{yr})$ than those observed in the 

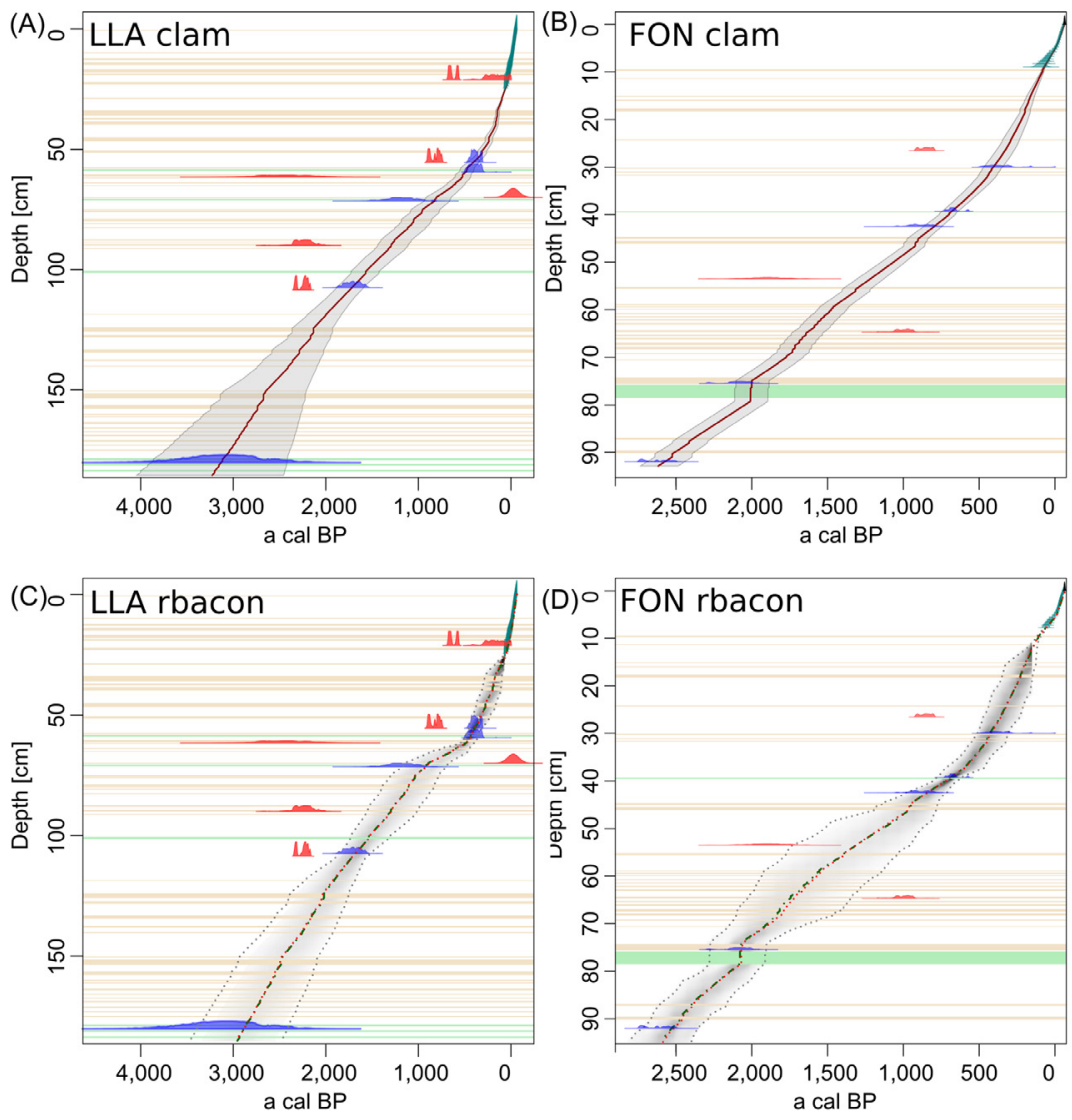

FIG. 3. Age-depth models for sediment cores from Lake Llaviucu (LLA, A and C), and Lake Fondococha (FON, B and D) comparing the output of clam (top row) and rbacon (bottom row) models, both with ${ }^{210} \mathrm{~Pb}$ ages near the surface (green) and ${ }^{14} \mathrm{C}$ calibratedage probability density curves (blue/red shapes). The ${ }^{14} \mathrm{C}$ dates on bulk sediment and insect chitin (red density curves) show substantial ${ }^{14} \mathrm{C}$ reservoir effects and were rejected. Event layers (orange horizontal bars) and tephra layers (green bars) are assumed to be deposited instantly. Model parameters are in supplementary Table S1; ${ }^{14} \mathrm{C}$ ages are in Table 2.

clam model. Prior to around 900 a cal BP, rbacon tends to model higher sedimentation rates than clam. This leads to the differences in the mean ages, but not in the range, modelled at $185 \mathrm{~cm}$ (rbacon: $c a .3,000$ a cal BP; clam: $c a .3,200$ a cal BP). The uncertainty ranges are better constrained in the top section of the core from Lake Llaviucu, which is mostly due to the higher ${ }^{14} \mathrm{C}$-sample frequency. Interestingly, the clam model returns a larger age uncertainty range for the bottom $c a .35 \mathrm{~cm}$ and its spread tends to increase with increasing depth. The rbacon model on the other hand, shows comparably stable uncertainty ranges from $c a$. 110 to $185 \mathrm{~cm}$.

The sediment core from Lake Fondococha extends back to $c a$. 2,600 a cal BP at $95 \mathrm{~cm}$. Five of the eight measured ${ }^{14} \mathrm{C}$ ages were used to build the age-depth models (Table 2). Like Lake Llaviucu, the sedimentation rate also increases in the most recent period and reaches values between 0.7 and $1 \mathrm{~mm} / \mathrm{yr}$ in the last century. Below $40 \mathrm{~cm}$, both models show comparable and relatively stable sedimentation rates. Average sedimentation rates for both age-depth models are $c a .0 .31 \mathrm{~mm} / \mathrm{yr}$, respectively, or $0.37 \mathrm{~mm} / \mathrm{yr}$ when the rapidly deposited layers are included (Fig. 3A, C). The clam model returns overall lower uncertainty ranges than the rbacon model (135 versus 357 years, respectively, averaged over the core). The latter shows the largest range between $c a .45 \mathrm{~cm}$ and $75 \mathrm{~cm}$, the longest core segment lacking acceptable ages. In contrast to Lake Llaviucu, the two age-depth modelling routines for Lake Fondococha produce similar ages. This can be explained with the narrower 
calibrated-age probability distribution of the oldest ${ }^{14} \mathrm{C}$ sample in Lake Fondococha compared to the relatively wider distribution in Lake Llaviucu.

\subsection{Tephra layer description}

Twenty-nine macroscopically discreet and cryptotephra layers were analysed from the four lakes (Fig. 4). The tephra layers are typically light to medium grey and range in thickness from a few millimetres to $2 \mathrm{~cm}$ (Table 3). Typical tephra morphologies are dense to moderately vesiculated glass shard (Fig. 5), with high Sr, Si, MS and, at times, Fe and Ti abundances. RAD count values are often low reflecting dense material (high X-ray absorption, high RAD inferred density; Fig. 2). Whole-core MS was not particularly useful to detect cryptotephra due to its coarse resolution.

In Lake Llaviucu, six visible layers were identified at depths from $60-66 \mathrm{~cm}$ in the multiple cores $(58.1 \mathrm{~cm}$, composite core depth), $70-78 \mathrm{~cm}(71.3 \mathrm{~cm}), 90-106 \mathrm{~cm}$ $(101.4 \mathrm{~cm}), 178.9 \mathrm{~cm}(179.2 \mathrm{~cm}), 180.9 \mathrm{~cm}$ $(181.4 \mathrm{~cm})$, and $183.7 \mathrm{~cm}(183.9 \mathrm{~cm})$. Hereafter, tephra layer depths are cited according to their bottom depth in the composite cores. Tephra layer LLA 58.1 is medium to dark grey, composed of crystal fragments, pumice and dense glass shards. Tephra layer LLA_71.3 is light to dark grey, composed of crystal fragments and moderately vesicular glass shards. This tephra layer is distinguished by high $\mathrm{Sr}, \mathrm{Si}, \mathrm{Ti}$, and $\mathrm{Fe}$ as well as by high RAD-inferred density. Tephra layer LLA_101.4 is mostly light grey, composed of crystal fragments, and dense glass shards. The proportion of crystal fragments is higher $(\sim 85 \%)$ in this layer than for others. This tephra layer is distinguished by high $\mathrm{Sr}$ counts. Tephra layer LLA_179.2 is medium grey, composed of crystal fragments and mostly dense glass shards. This tephra layer also generates high $\mathrm{Sr}$ counts. Tephra layer LLA_181.4 is medium to dark grey and mostly composed of pumice. This tephra layer is distinguished by high $\mathrm{Si}$ and Fe counts. Finally, layer LLA_183.9 is medium to dark grey and mostly composed of crystal fragments. This oldest tephra layer has high $\mathrm{Sr}$ and $\mathrm{Si}$ counts.

The ages of tephra layers in Lake Llaviucu range from 3.2 to $0.4 \mathrm{ka}$ (Table 4). The age uncertainty is large ( $> \pm 400$ years) for the three oldest layers.
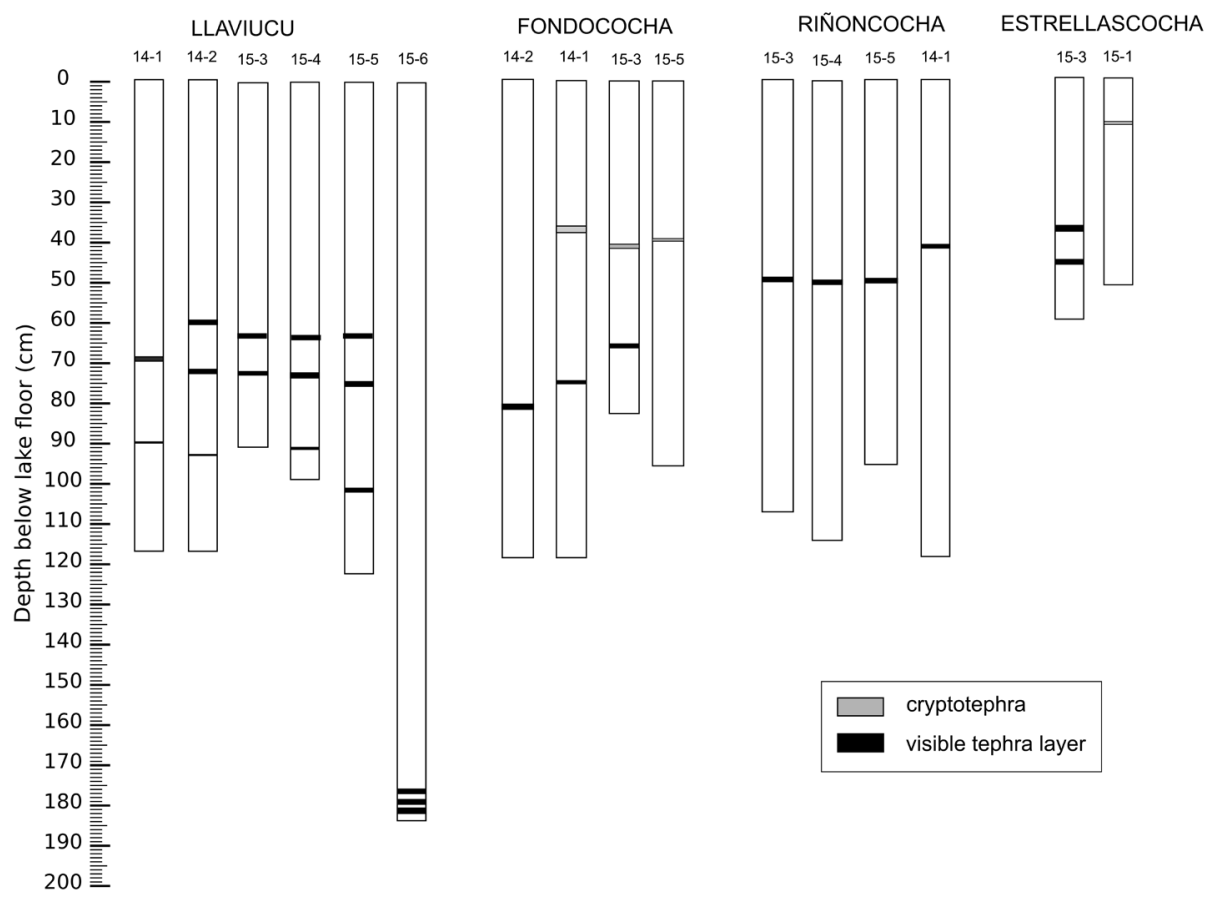

FIG. 4. Visible (black) and cryptotephra layers (grey) found in each of the sediment cores from four lakes arranged from lowest (Lake Llaviucu) to highest (Lake Estrellascocha) elevation. 
TABLE 3. TEPHRA BED PHYSICAL CHARACTERISTICS.

\begin{tabular}{|c|c|c|c|c|}
\hline Tephra layer ID* & $\begin{array}{l}\text { Thickness } \\
\quad(\mathrm{cm})\end{array}$ & General colour & $\begin{array}{l}\text { Componentry \% } \\
\text { (Crystal fragment/ } \\
\text { glass shard/ } \\
\text { pumice) }\end{array}$ & Glass shards description \\
\hline LLA14-2_60.0 & 0.8 & Light to dark grey & $90 / 0 / 10$ & All dense \\
\hline LLA15-3_64.0 & 1 & Medium to dark grey & $50 / 5 / 45$ & Mostly dense, few moderately vesiculated \\
\hline LLA15-4_64.0 & 1 & Medium to dark grey & $50 / 5 / 45$ & Mostly dense, few moderately vesiculated \\
\hline LLA15-5_66.0 & 1 & Medium to dark grey & $50 / 5 / 45$ & Mostly dense, few moderately vesiculated \\
\hline LLA14-1_70.7 & 0.5 & Medium grey & - & Mostly dense, some moderately vesiculated, few shards \\
\hline LLA14-2_73.7 & 0.4 & Medium grey & $40 / 50 / 10$ & Mostly dense, some moderately vesiculated, few shards \\
\hline LLA15-4_75.0 & 1 & Light to dark grey & $40 / 35 / 25$ & Mostly dense, some moderately vesiculated \\
\hline LLA15-3_77.0 & 1 & Light to dark grey & $40 / 35 / 25$ & $\begin{array}{l}\text { Mostly dense, some moderately vesiculated, few } \\
\text { vesicular }\end{array}$ \\
\hline LLA15-5_78.0 & 1 & Light to dark grey & $40 / 35 / 25$ & $\begin{array}{l}\text { Mostly dense, some moderately vesiculated, few } \\
\text { vesicular }\end{array}$ \\
\hline LLA14-1_90.4 & 0.5 & Light grey & - & All dense \\
\hline LLA14-2_94.8 & 0.4 & Light grey & $75 / 0 / 25$ & All dense \\
\hline LLA15-4_95.0 & 0.5 & Light to dark grey & $85 / 0 / 15$ & All dense \\
\hline LLA15-5_106.0 & 1 & Light to dark grey & $85 / 0 / 15$ & All dense \\
\hline LLA15-6_178.9 & 0.85 & Medium grey & $45 / 50 / 5$ & $\begin{array}{l}\text { Mostly dense, some moderately vesiculated, some } \\
\text { shards, few vesiculated }\end{array}$ \\
\hline LLA15-6_180.9 & 1.2 & Medium to dark grey & $15 / 10 / 75$ & Mostly dense, some moderately vesiculated \\
\hline LLA15-6_183.9 & 0.8 & Medium to dark grey & $60 / 35 / 5$ & Mostly dense, some shards, few vesiculated \\
\hline FON14-1_39.8 & 1.3 & Light to medium grey & $15 / 85 / 0$ & $\begin{array}{l}\text { Mostly moderately vesiculated, some dense, few } \\
\text { vesicular, few shards }\end{array}$ \\
\hline FON15-5_40.0 & 0.2 & Light to dark grey & $40 / 55 / 5$ & $\begin{array}{l}\text { Mostly dense, some moderately vesiculated, few } \\
\text { vesiculated, few shards }\end{array}$ \\
\hline FON15-3_42.5 & 0.2 & Light to dark grey & $40 / 55 / 5$ & $\begin{array}{l}\text { Mostly dense, some moderately vesiculated, few } \\
\text { vesiculated, few shards }\end{array}$ \\
\hline FON15-3_68.0 & 1 & Light to dark grey & $5 / 95 / 0$ & $\begin{array}{l}\text { Mostly moderately vesiculated, some vesiculated, few } \\
\text { shards, few dense }\end{array}$ \\
\hline FON14-1_75.4 & 1.1 & & $0 / 100 / 0$ & $\begin{array}{l}\text { Mostly moderately vesiculated, some dense, some } \\
\text { vesiculated }\end{array}$ \\
\hline FON14-2_81.3 & 1 & Light to medium grey & $20 / 75 / 5$ & Mostly moderately vesiculated, some dense, few shards \\
\hline RIN14-1_41.5 & 1.2 & Light to dark grey & $0 / 100 / 0$ & Mostly moderately vesiculated, few dense, few shards \\
\hline RIN15-3_51.0 & 1 & Light to dark grey & $0 / 100 / 0$ & Mostly vesiculated, some moderately vesiculated \\
\hline RIN15-4_51.0 & 1 & Light to dark grey & 0/100/0 & Mostly vesiculated, some moderately vesiculated \\
\hline RIN15-5_51.0 & 1 & Light to dark grey & $0 / 100 / 0$ & Mostly vesiculated, some moderately vesiculated \\
\hline EST15-1_11.5 & 0.4 & Dark grey & $20 / 75 / 5$ & Mostly dense, few moderately vesiculated, few shards \\
\hline EST15-3_38.5 & 1.4 & Medium to dark grey & $35 / 65 / 0$ & $\begin{array}{l}\text { Some dense, some moderately vesiculated, few } \\
\text { vesiculated glass }\end{array}$ \\
\hline EST15-3_47.6 & 1 & Light grey & $0 / 100 / 0$ & Mostly dense, few shards \\
\hline
\end{tabular}

* Numbers at the end of the tephra layer IDs indicate the bottom depth of the tephra layers based on the composite cores. The three letters at the beginning of each tephra layer ID refers to the lake: FON: Fondococha; LLA: Llaviucu; EST: Estrellascocha; and RIN: Riñoncocha 

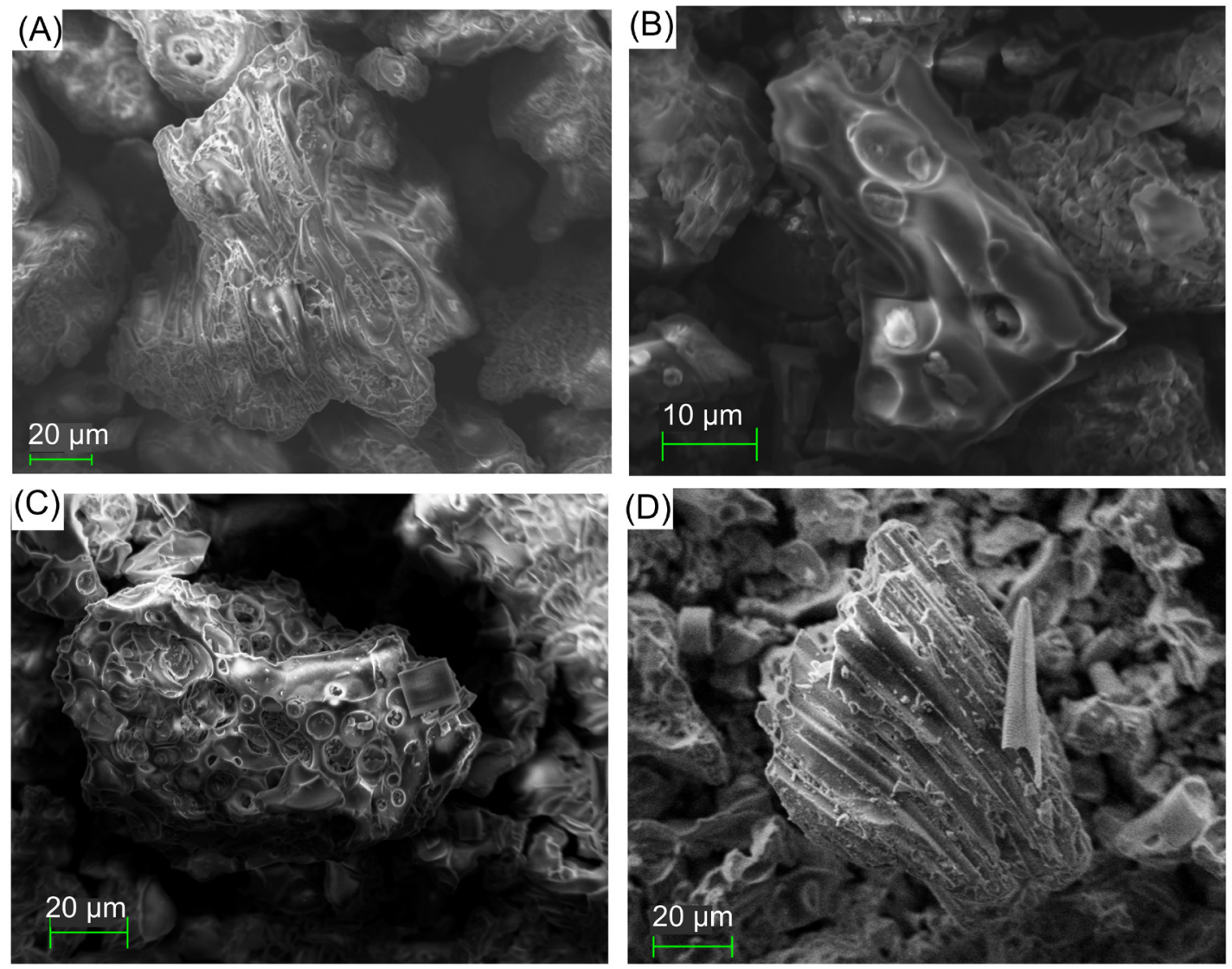

FIG. 5. Scanning electron micrographs of typical glass shards for A. Tephra layer LLA15-6_180.9 in Lake Llaviucu, B. Tephra layer FON14-1_39.8 in Lake Fondococha, C. Tephra layer RIN15-3_51 in Lake Riñoncocha, and D. Tephra layer EST15-3_38.5 in Lake Estrellascocha.

TABLE 4. TEPHRA LAYER BEST AGE ESTIMATES (a cal BP). BASED ON RBACON AND CLAM AGE-DEPTH MODELS.

\begin{tabular}{lcccccccc}
\hline Tephra layer ID* & \multicolumn{3}{c}{ Clam } & \multicolumn{3}{c}{ Rbacon } & \multicolumn{2}{c}{$\begin{array}{c}\text { Best age } \\
\text { estimate** }\end{array}$} \\
\cline { 2 - 6 } & Median & Min 95\% & Max 95\% & Median & Min & Max & \\
\hline LLA_58.1 & 470 & 543 & 395 & 432 & 480 & 346 & 450 & 70 \\
LLA_71.3 & 822 & 936 & 659 & 917 & 1,158 & 692 & 857 & 180 \\
LLA_101.4 & 1,568 & 1,729 & 1,425 & 1,542 & 1,736 & 1,324 & 1,557 & 177 \\
LLA_179.2 & 3,114 & 3,861 & 2,414 & 2,861 & 3,372 & 2,403 & 2,962 & 592 \\
LLA_181.4 & 3,152 & 3,923 & 2,424 & 2,893 & 3,409 & 2,432 & 2,995 & 605 \\
LLA_183.9 & 3,198 & 3,999 & 2,443 & 2,930 & 3,452 & 2,462 & 3,034 & 621 \\
FON_39.8 & 698 & 762 & 659 & 687 & 780 & 626 & 694 & 63 \\
FON_75.6 & 2,001 & 2,112 & 1,896 & 2,071 & 2,281 & 1,913 & 2,027 & 141 \\
\hline
\end{tabular}

* Numbers at the end of the tephra layer ID indicate the composite depth $(\mathrm{cm})$.

** Calculations in supplementary Table S2. 
These layers are separated from each other by approximately $2 \mathrm{~mm}$ of sediment, implying an age difference of about 4 years based on the average sedimentation rate. The ages of the tephra layers differ little between clam and rbacon models.

In the sediment of Lake Fondococha, two tephra layers were found at depths $39.8-42.5 \mathrm{~cm}(39.8 \mathrm{~cm}$, composite depth) and $68-81.3 \mathrm{~cm}(75.6 \mathrm{~cm})$. Tephra layer FON_39.8 is light to dark grey, mostly composed of moderately vesiculated glass shards. This tephra layer has high $\mathrm{Sr}$ counts and high RAD-inferred density. Visible tephra layer FON_75.6 is light to dark grey and composed almost entirely of moderately vesiculated glass shards. This second tephra layer shows high $\mathrm{Sr}$ and Si counts as well as high RADinferred density. The choice of the age-depth model does not influence the assigned tephra layer ages.

In Lake Riñoncocha, one visible tephra layer was identified at $41.5-51.0 \mathrm{~cm}(41.5 \mathrm{~cm}$ based on core LLA14-1). Tephra layer RIN 41.5 is light to dark grey and entirely composed of vesiculated glass shards. This unique tephra layer is distinguished by high RAD-inferred density and high $\mathrm{Sr}, \mathrm{Si}, \mathrm{Fe}$, and Ti counts. Insufficient organic material was available for a radiocarbon age determination from sediment immediately below this tephra layer.

Finally, in Lake Estrellascocha, three tephra layers were identified at depths of $11.5 \mathrm{~cm}, 38.5 \mathrm{~cm}$, and $47.6 \mathrm{~cm}$; in addition, several more cryptotephra layers may be present, but were not investigated in the present study (Fig. 2). Cryptotephra layer EST 11.5 is dark grey and mainly composed of dense glass shards. This layer shows high $\mathrm{Sr}, \mathrm{Si}$, $\mathrm{Ti}$, and Fe counts as well as moderately high MS values. Visible tephra layer EST_38.5 is medium to dark grey with mostly moderately vesiculated glass shards. This second layer shows high $\mathrm{Sr}, \mathrm{Si}$, $\mathrm{Ti}$, and $\mathrm{Fe}$, and low $\mathrm{Cu}$. Finally, visible tephra layer EST_47.6 is dark grey and entirely composed of dense glass shards. This third layer shows high Ti, $\mathrm{Fe}$, and Si counts and high MS values.

In several instances, tephra beds were not present in every core from the same lake, although could have been present as an unexamined cryptotephra layer. For example, FON15-5 contained a single cryptotephra layer (FON15-5_40) and no visible layers even though core FON15-3, taken nearby, contained both (FON15-3_42.5 and FON15-3_68) (Fig. 4). Cryptotephra might be present but were not detected from each lake and from Lake Estrellascocha
(Fig. 2) in particular. For example, small peaks in $\mathrm{Sr}$ are visible for Lake Estrellascocha at depths where no cryptotephra layers were found (Fig. 2). Additionally, at least one bed appears to be present at only one site (e.g., EST15-1_11.5).

\subsection{Tephra layer correlation}

Tephra layers were correlated between Lakes Llaviucu and Fondococha based on their age-depth models. Various techniques were used to correlate tephra layers in the undated sediments of Lakes Riñoncocha and Estrellascocha. One layer is correlated between Lakes Llaviucu and Fondococha based on the overlap of their age (LLA_71.3 and FON_39.8, Table 4). Another correlation between those two lakes is made but is poorly constrained (LLA_101.4 and FON_75.6), and one more correlation to undated Lake Riñoncocha is based on PCA results conducted on the $\mu$ XRF data (FON_75.6 and RIN_41.5, Fig. 6). The tephrochronology for all lakes is summarized in figure 7 .

\subsubsection{Tephra layer LLA_183.9 cm}

This tephra layer was sampled from the sediment core of Lake Llaviucu (LLA15-6 183.9). The large uncertainty in the best age estimate for this tephra layer $(3,034 \pm 621$ a cal BP) precludes correlations with Lake Fondococha. Correlations to Lake Riñoncocha and Estrallascocha are not supported by elemental composition or componentry.

\subsubsection{Tephra layer LLA_181.4 cm}

This tephra layer was sampled from Lake Llaviucu (LLA15-6_180.9). Like the previous tephra layer, the large uncertainty in the best age estimate $(2,995 \pm$ 605 a cal BP) precludes correlations based on chronology. Sediment separates tephra layer LLA_183.7 from LLA_181.4 yet PCA indicates close similarity between the two layers (Fig. 6). Correlations to Lake Riñoncocha and Estrellascocha are not supported by elemental composition or componentry.

\subsubsection{Tephra layer LLA_179.2 cm}

Like the previous two tephra layers, this tephra layer was sampled from Lake Llaviucu sediment core (LLA15-6_178.9) and the large uncertainty in the best age estimate $(2,962 \pm 592$ a cal BP) also precludes possible correlations with tephra layers in Lake Fondococha. Sediment separates tephra layer 

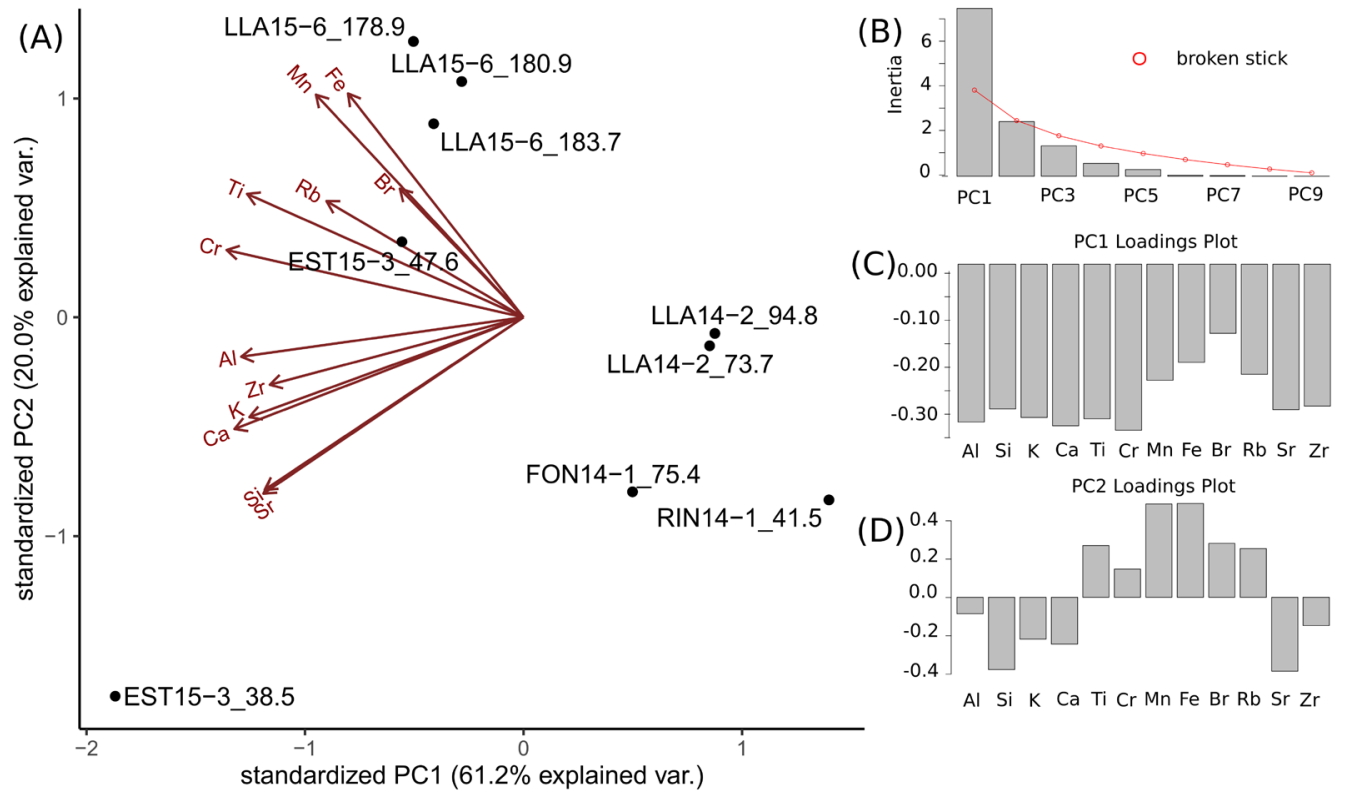

PC2 Loadings Plot

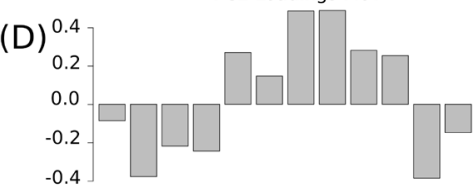

Al Si K Ca $\mathrm{Ti} \mathrm{Cr} \mathrm{Mn} \mathrm{Fe} \mathrm{Br} \mathrm{Rb} \mathrm{Sr} \mathrm{Zr}$

FIG. 6. A. Principal component analysis of $\mu$ XRF data used to aid correlation of visible tephra beds among the lakes; B. The broken stick model indicates one significant principal component (PC): Standardized PC1 explains $62.1 \%$ of the geochemical variance and primarily distinguishes tephra samples based on $(\mathbf{C}$ and $\mathbf{D})$ the loadings of elements $\mathrm{Al}$ to $\mathrm{Zr}$.

LLA_181.4 from LLA_179.2 yet once again PCA indicates close similarity between layers LLA 181.4 and LLA_179.2 and layer LLA183.9. Furthermore, correlations to either Lake Riñoncocha or Lake Estrellascocha are not supported by elemental composition or componentry.

\subsubsection{Tephra layer LLA_101.4 cm}

The next tephra layer is sampled in four cores from Lake Llaviucu with a best age estimate of $1,557 \pm$ 177 a cal BP. A tephra layer at the same stratigraphic location but with different elemental composition as seen from PCA (Fig. 6) is FON_75.6 found in three cores of Lake Fondococha. Both show high Sr levels (Fig. 2), although differ in Si. Their componentries are also different, with Lake Fondococha's tephra layers mostly composed of glass, whereas Lake Llaviucu's tephra layers are mostly crystal fragments (Table 3). Furthermore, the best age estimate for this tephra layer in Lake Fondococha does not overlap and is older (2,027 \pm 141 a cal BP). Considering the conflicting and inconclusive evidence, it is unclear whether tephra layer LLA 101.4 and FON 75.6 are the same. In contrast, confidence is higher for the correlation of this tephra layer between Lake Fondococha and undated Lake Riñoncocha. Tephra layers FON_75.6 and RIN_41.5 are similar in elemental composition as seen from PCA (Fig. 6), componentry as well as colour (Table 3).

\subsubsection{Tephra layer $L L A \_71.3 \mathrm{~cm}$}

Tephra layer LLA $71 . \overline{3}$ is found in four cores from Lake Llaviucu, with a best age estimate of $857 \pm 180$ a cal BP. Its age overlaps with the best age estimate of $694 \pm 63$ a cal BP for Lake Fondococha's tephra layer FON_39.8. However, no other supporting evidence for this correlation exists. As the tephra layers in Lake Fondococha are cryptotephras, PCA analysis could not be applied. Tephra layer characteristics were variable, and correlations are made with low confidence. A best age estimate for this tephra layer using both lakes is $733 \pm 112$ a cal BP. No evidence supports correlations to tephra layers found in either Lake Riñoncocha's or Lake Estrellascocha's sediment.

\subsubsection{Tephra layer LLA_58.1 cm}

The youngest dated tephra layer was sampled in three cores from Lake Llaviucu's sediment with a 


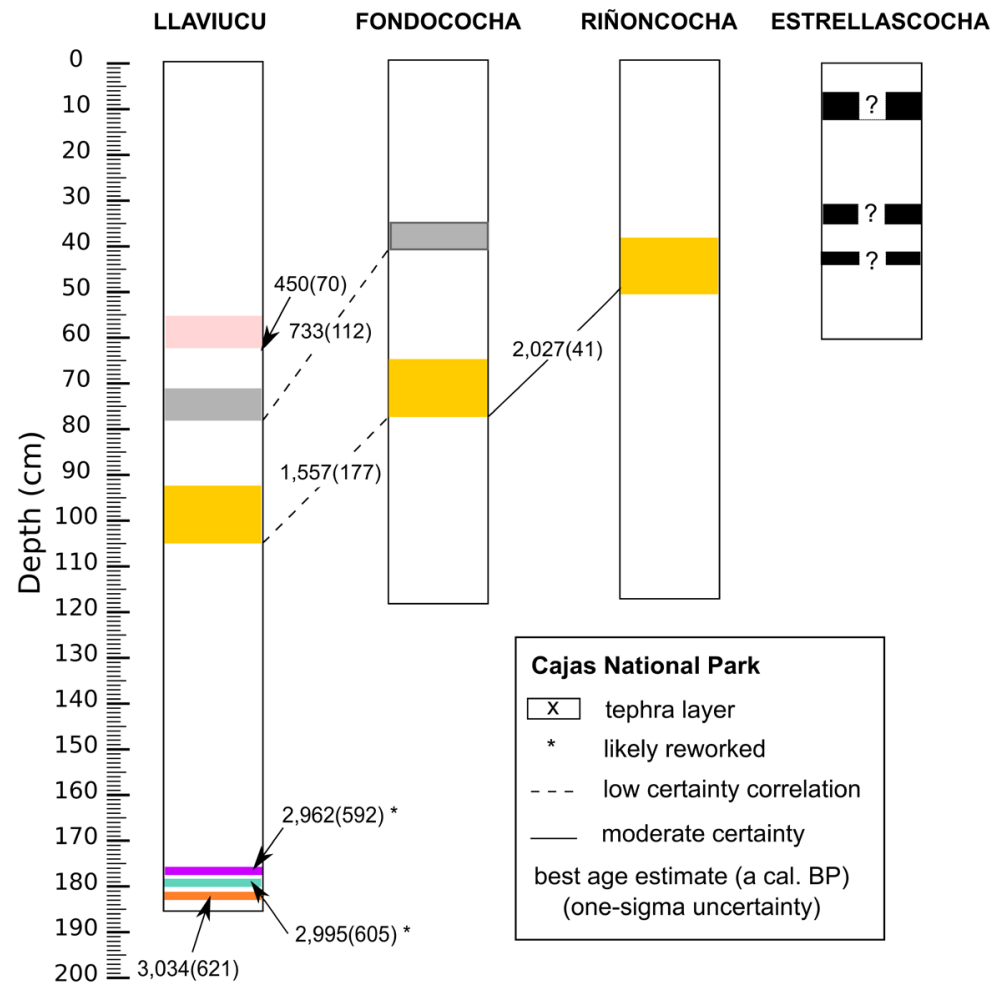

FIG. 7. Simplified stratigraphic sequence showing depths below lake floor, thicknesses and correlations among tephra layers found in sediment cores from the four lakes. The best age estimates in a cal BP and the one sigma uncertainties (in brackets) calculated from the clam and rbacon age-depth models are shown. Note that the Llaviucu schematic represents the composite core.

best age estimate of $450 \pm 70$ a cal BP. No evidence supports the correlation of this tephra layer to tephra layers detected in either Lake Riñoncocha or Lake Estrellascocha.

\section{Discussion and conclusion}

Lake sediments are generally reliable archives for catching and preserving tephra layers, and geographically distributed lakes are useful for documenting the extent of volcanic fallout (Lowe, 2011). However, from our results, some tephra layers appear to be missing from a few sites within the same lake, indicating that one core is not enough to confidently capture all the tephra falls. Heterogeneous areal distribution of tephra fallout deposition within a lake has been previously documented (Boygle, 1999; Kylander et al., 2012; Pyne-O’Donnell, 2011). Although there is no obvious spatial pattern to the missing tephra layers, it is likely that currents concentrate tephra in places on the lake floor, that wind recirculates tephra, and that sediment mixing can obliterate visual evidence of a tephra at some locations.

In addition, some lakes have captured more tephra fall events than others. Lake Llaviucu's sediment cores contain six tephra layers compared to two in Lake Fondococha and one in Lake Riñoncocha. However, it should be noted that Lake Llaviucu likely contains reworked tephra layers, as discussed below. Similar differences were highlighted by de Fontaine et al. (2007) who identified five times as many tephra layers in one lake $40 \mathrm{~km}$ away from another in south-central Alaska. Whereas the authors explained the differences through a host of catchment-basin and taphonomic reasons, it appears that catchment-to-lake area ratio is the property most likely affecting the variation seen in our study, with larger ratios associated with more frequent tephra beds. The delivery of tephra from the catchment into 
the lake influences the tephra layer thickness. The greater number of tephra layers may be explained by Lake Llaviucu's much larger catchment-to-lake area ratio compared to the other lakes. Six tephra layers are found in Lake Llaviucu, with catchment-to-lake area ratio of 252, three in Lake Estrellascocha with a ratio of 12, two in Lake Fondococha with a ratio of 18 , and one in Lake Riñoncocha with ratio of 6 . Sedimentation rates unlikely play a role because they are similar in at least Lakes Fondococha and Llaviucu.

The presence of more tephra layers in Lake Llaviucu may also be explained by reworking of tephra from the catchment or within the lake decades after an eruption. Tephra layers LLA_178.9 and LLA_180.9 are candidate layers for reworking. Evidence for progressively more dilute glass concentration in LLA_178.9 and LLA_180.9 supports this hypothesis. Additionally, the sedimentary record of Lake Llaviucu contains many flood event layers, which combined with a large catchment, could rework tephra from the drainage basin over time through fluvial and runoff transport (Pyne-O'Donnell, 2011). Three consecutive eruptions (tephra layers LLA_183.9, LLA_180.9, and LLA_178.9) would be surprising but not unheard of. For example, Tungurahua is a highly active volcano that could have erupted three times in less than 100 years as evidenced by the eight eruptions during the documented 1999-2014 eruptive cycle (Bustillos et al., 2017). However, based on the sedimentation rate, only $\sim 4$ years separate the layers from each other and from the oldest layer, LLA_183.9, and would suggest specific and recurring wind directions. Finally, the similarity between the layers as seen from PCA could indicate reworking. Previous studies have demonstrated that layers of similar composition are likely to indicate reworking (Hopkins et al., 2015)

Both clam and rbacon models were calculated and compared to understand the strengths and disadvantages of the different age-depth models. The differences in the uncertainty ranges (shadings in Fig. 3) result from the different initial model parameters as well as the model calculations (Trachsel and Telford, 2017; Blaauw et al., 2018). Although the assumptions differ between models (Blaauw et al., 2018), the ages of tephra layers overlap even with average dating densities (one date per millennium). This can be attributed to ${ }^{14} \mathrm{C}$ ages that were taken from close to the tephra layers. The calculated best-age- estimate further constrains the uncertainties native to individual age-depth modelling approaches. We therefore suggest that the presented tephra layer ages are relatively robust.

Up to now, one study has investigated tephra fallout in southern Ecuador during the Holocene, but found no prominent tephra layers in the past 2,000 years (Rodbell et al., 2002). This led the authors to suggest that wind trajectories had shifted. However, our discovery of possibly three tephra layers during this interval (two if LLA_101.4 and FON_75.6 are the same) and one more around 3,000 a cal BP, with one of the five traceable across at least two sites, indicates that wind conditions were likely not much different in the late Holocene. The lack of tephra layers in the previous study can likely be attributed to focusing on one core per lake or the lack of methodology suitable to detect cryptotephra and underscores our conclusion that more than one core is needed to fully account for tephra fallout events.

Nevertheless, Rodbell et al. (2002) identified two tephra layers (G and F, in their Fig. 3) in Lakes Pallcacocha, Chorreras, and Llaviucu that could correlate with the tephra layers described in our study. Tephra layers G and F in Lake Pallcacocha may correspond to FON_75.6 in terms of age but may be older than LLA_101.4. Based on their ages, tephra layers $\mathrm{G}$ and $\mathrm{F}$ in Lake Chorreras may correspond to two of the oldest three tephra layers in Lake Llaviucu, either LLA_183.9, LLA_181.4 or LLA_179.2. In detail, the age ascribed to tephra layer $\mathrm{G}(3,380+60$, -100 a cal BP, Rodbell et al., 2002) falls within the age range of all three oldest Lake Llaviucu tephra layers and within the age range of the Tungurahua eruption described by Le Pennec et al. (2013) (ca. 3,050 a cal BP). However, evidence suggests that two of the three oldest Lake Llaviucu layers (LLA_181.4 and LLA_179.2) may be reworked.

Correlations with known eruptions were attempted using estimated tephra layer age. Until further evidence is available, only LLA_183.9 of the three oldest Llaviucu layers is considered as a primary tephra. Tungurahua (volcano 4 in Fig. 1) erupted $c a$. 3,000 a cal BP, initiating two lahars and causing disruption of local communities (Hall et al., 1999; Le Pennec et al., 2012, 2013). It is likely that the oldest tephra layer found in Lake Llaviucu's sediment (LLA_183.9) represents one eruption from Tungurahua (Table 5).

The next two tephra layers, FON_75.6 and LLA_101.4, are inconclusively correlated, and 
TABLE 5. BEST AGE ESTIMATES AND CANDIDATE ERUPTION EVENTS FOR FOUR TEPHRA LAYERS FROM CAJAS NATIONAL PARK.

\begin{tabular}{|c|c|c|c|c|c|}
\hline \multirow{2}{*}{ Tephra layer ID } & \multicolumn{2}{|c|}{ Best age estimate } & \multirow{2}{*}{$\begin{array}{c}\text { Candidate } \\
\text { volcano(es) } \dagger\end{array}$} & \multirow{2}{*}{$\begin{array}{l}\text { Eruption } \\
\text { (a cal BP) }\end{array}$} & \multirow{2}{*}{ References } \\
\hline & a cal BP & $\pm 1 \mathrm{SD}$ & & & \\
\hline LLA_58.1 & 450 & 70 & Cotopaxi $^{2}$ & $418^{\S}$ & Barberi et al. (1995) \\
\hline \multirow[t]{2}{*}{ LLA_71.3 } & 733 & 112 & Tungurahua $^{4}$ & $605 \pm 32 *$ & Le Pennec et al. (2008) \\
\hline & & & Quilotoa $^{1}$ & $\sim 800$ & Mothes and Hall (2008) \\
\hline \multirow[t]{3}{*}{ LLA_101.4 } & 1,557 & 177 & Tungurahua ${ }^{4}$ & $1,483 *$ & Venzke (2016) \\
\hline & & & Cotopaxi $^{2}$ & $1,510 \pm 212 *$ & Venzke (2016) \\
\hline & & & Chimborazo $^{3}$ & $1,530 \pm 50$ & Barba et al. (2008) \\
\hline \multirow[t]{2}{*}{ FON_75.6 } & 2,027 & 41 & Tungurahua $^{4}$ & $2,020^{*}$ & Venzke (2016) \\
\hline & & & Cotopaxi $^{2}$ & $2,023 \pm 107^{*}$ & Barberi et al. (1995) \\
\hline LLA_183.9 & 3,034 & 621 & Tungurahua $^{4}$ & $3,117 \pm 124 *$ & Hall et al. (1999) \\
\hline
\end{tabular}

* Ages calibrated from the originally reported uncalibrated ages.

$\S$ Historical account.

$\uparrow$ Superscript number represents volcano ID in figure 1 .

might have been erupted from different sources. The age of tephra layer FON_75.6 (2,027 \pm 41 a cal BP) overlaps with the age of large eruptions from Tungurahua (volcano 4 in Fig. 1; Venzke, 2016) and from Cotopaxi (volcano 2 in Fig. 1; Barberi et al., 1995) (Table 5). Similarly, the age of LLA_101.4 overlaps with other eruptions from the same two volcanoes (Venzke, 2016). Additionally, LLA_101.4 could correspond to an eruption from Chimborazo (volcano 3 in Fig. 1) (Barba et al., 2008). Few records of eruptions from Sangay, the closest volcano to $\mathrm{CNP}$, exist prior to 500 a cal BP making this volcano another candidate. A tephra layer of similar age $(1,470$ a cal BP) in Lake Baños was attributed to the volcano Antisana (Matthews-Bird et al., 2017) but both are located in northern Ecuador at a significant distance from CNP. Considering the distance between the lakes and the volcanoes, it is most likely that the tephra layers represent eruptions from Tungurahua.

The age of the next dated tephra layer, LLA_71.3 at $733 \pm 112$ a cal $\mathrm{BP}$, overlaps with two known eruptions. The first is from the devastating Quilotoa (volcano 1 in Fig. 1) eruption ca. 800 a cal BP, likened in scale to the 1991 Pinatubo eruption (Mothes and Hall, 1998, 2008). Tephra fallout from that eruption was found $c a .160 \mathrm{~km}$ south from the vent (Mothes and Hall, 2008), suggesting ash could have reached CNP. Ash from this eruption was possibly found in Laguna Pindo, $112 \mathrm{~km}$ east of Quilotoa (Matthews-Bird et al., 2017). The second is from Tungurahua during an active period $c a .600 \mathrm{a}$ cal BP (Le Pennec et al., 2008). Both volcanoes are a similar distance away from the lakes. Ash fallout from Tungurahua was modelled to have reached as far south as CNP during eruptions in 1999 and 2001 (Le Pennec et tephra erual., 2012), but evidence for these particular eruptions has not been found in the lake sediment. Although several source volcanoes have been mentioned, all tephra layers previously discussed can be attributed to eruptions from one nearby volcano, Tungurahua.

Finally, and unlike the others, tephra layer LLA_58.1 (450 \pm 70 a cal BP) best matches the historical Cotopaxi eruption of 418 a cal BP (Table 5) (Barberi et al., 1995). No Tungurahua eruption has been recorded around that time. However, insufficient evidence is available from our study to suggest this tephra layer has a different elemental composition from the tephra layers previously described. The four or five layers identified provide additional information on eruption magnitude and wind direction. Although the thickness of a tephra layer is not always correlated with the magnitude of an eruption because plume trajectories vary among eruptions, the new results add to the knowledge of the extent and volume of tephra deposition during different eruptions. Previous 
research suggested that volcanic ash did not reach CNP during the Late Holocene, implying a change in wind direction, a decrease in eruption magnitude, or both (Rodbell et al., 2002). Here we demonstrate that eruption magnitude, wind direction or both have likely not changed substantially during the last 2,000 years as compared to the Late Glacial. This suggests that volcanic eruptions will likely remain a hazard for southern Ecuador, where tephra has fallen on average every $\sim 500$ years at a minimum and likely more frequently.

In conclusion, five tephra layers were identified from 29 visible and cryptotephra layers preserved in multiple sediment cores from four lakes in CNP. Chronologies were developed from two of the lakes and one tephra layer could be correlated based on age. Correlations with the other two lakes were based on elemental composition, colour, and componentry. Tephra layer LLA_183.9 was followed by two reworking events, LLA_181.4, and LLA_179.2, closely spaced in time $(3,034 \pm 621,2,995 \pm 605$, and 2,962 \pm 592 a cal BP, respectively) as preserved in Lake Llaviucu. These are followed by tephra

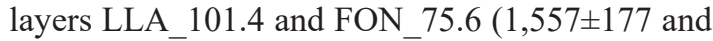
$2,027 \pm 41$ a cal $\mathrm{BP}$, respectively), that due to age uncertainty and limited physical evidence, cannot be unambiguously attributed to the same eruption. Tephra layer LLA_71.3 $(733 \pm 112 \mathrm{a}$ cal BP) is correlated across two lakes. Tephra LLA_58.1 (450 $\pm 70 \mathrm{a}$ cal BP) is only found in Lake Llaviucu. Three tephra layers were also found in Lake Estrellascocha but could not be correlated.

The first study in this region provided a starting point but had not found any events during the last 2,000 years likely because that study focused on thick layers in only one core (Rodbell et al., 2002). Here we document probably three events over the last 2,000 years. As evidenced from our study, some tephra layers appeared to be missing from one of the cores of the depocenters, and some lakes recorded more events than others, leading us to conclude, like previous work before us, that one core or one lake is not enough to confidently capture all the tephra layers from surrounding volcanoes (e.g., Boygle, 1999; Kaufman et al., 2012). Additionally, a systematic search using emerging cryptotephra techniques (Davies, 2015), which was not performed in this study, should yield evidence for even more events. The addition of four or five marker events is a significant contribution for future studies of lake sediments in Cajas National
Park where radiocarbon dating is often challenging. While a systematic survey of lakes in southern Ecuador would be needed to produce a history of eruption frequency, the presence and abundance of tephra layers during the Late Holocene indicate that volcanic eruptions are a greater hazard to southern Ecuador than previously reported.

\section{Acknowledgements}

This work was supported by the Swiss National Science Foundation grant 200021_152986. MG designed the research. S.H. Arcusa, M. Grosjean, T. Schneider, and P. Mosquera, collected the cores. S.H. Arcusa and T. Schneider did the sedimentological analyses and agedepth modelling. S.H. Arcusa, T. Schneider, and H. Vogel, scanned the cores with ITRAX, P. Mosquera collected bathymetry data and created the maps, and S.S. Szidat made the radiocarbon measurements. S.H. Arcusa, T. Schneider, and D. Kaufman wrote the paper, all authors commented on the drafts. S.H. Arcusa and T. Schneider designed the figures. We thank Dr. D. Fischer for the lab assistance, E. Vogel as well as Dr. G. Salazar for support of AMS analysis, P. Bornhauser-Kaltenrieder for the macrofossil identification and Dr. F. Anselmetti for assistance with the MSCL scans. We also thank Dr. S. Wastegard and two anonymous reviewers for their constructive comments.

\section{Declarations of competing interest}

The authors declare that they have no known competing financial interests or personal relationships that could have appeared to influence the work reported in this paper.

\section{Data availability}

The data and calculations presented in this manuscript are uploaded online at https://boris.unibe.ch/146277/ (BORIS, Uni Bern) (last visit 03/09/2020).

\section{References}

Alloway, B.V.; Lowe, D.J.; Larsen, G.; Shane, P.A.R.; Westgate, J.A. 2013. Tephrochronology. Encyclopedia of Quaternary Science: 277-304.

Bandowe, B.A.M.; Fränkl, L.; Grosjean, M.; Tylmann, W.; Mosquera, P.V.; Hampel, H.; Schneider, T. 2018. A 150-year record of polycyclic aromatic compound (PAC) deposition from high Andean Cajas National Park, southern Ecuador. Science of the Total Environment 621: 1652-1663. doi: 10.1016/j.scitotenv.2017.10.060.

Barba, D.; Robin, C.; Samaniego, P.; Eissen, J.P. 2008. Holocene recurrent explosive activity at Chimborazo 
volcano (Ecuador). Journal of Volcanology and Geothermal Research 176: 27-35.

Barberi, F.; Coltelli, M.; Frullani, A.; Rosi, M.; Almeida, E. 1995. Chronology and dispersal characteristics of recently (last 5000 years) erupted tephra of Cotopaxi (Ecuador): implications for long-term eruptive forecasting. Journal of Volcanology and Geothermal Research 69: 217-239. doi: 10.1016/0377-0273(95)00017-8.

Blaauw, M. 2019. Clam: Classical age-depth modelling of cores from deposits. $\mathrm{R}$ package version 2.3.2. https://CRAN.R-project.org/package $=$ clam (last visit 03/09/2020).

Blaauw, M.; Christen, J.A. 2019. Rbacon: Age-depth modelling using bayesian statistics. R package version 2.3.9.1. https://CRAN.R- project.org/package=rbacon. (last visit 03/09/2020).

Blaauw, M.; Christen, J.A.; Bennett, K.D.; Reimer, P.J. 2018. Double the dates and go for Bayes-Impacts of model choice, dating density and quality on chronologies. Quaternary Science Reviews 188: 58-66.

Boygle, J. 1999. Variability of tephra in lake and catchment sediments, Svínavatn, Iceland. Global Planetary Change 21: 129-149. doi: 10.1016/j.quascirev.2018.03.032.

Bustillos, J.; Romero, J.E.; Guevara, A.; Díaz-Alvarado, J. 2018. Tephra fallout from the long-lasting Tungurahua eruptive cycle (1999-2014): Variations through eruptive style transition and deposition processes. Andean Geology 45 (1): 47-77. doi: 10.5027/andgeoV45n1-3036.

Butz, C.; Grosjean, M.; Fischer, D.; Wunderle, S.; Tylmann, W; Rein, B. 2015. Hyperspectral imaging spectroscopy: a promising method for the biogeochemical analysis of lake sediments. Journal of Applied Remote Sensing 9: 1-20. doi:10.1117/1.JRS.9.096031.

Buytaert, W.; Deckers, J.; Wyseure, G. 2006. Description and classification of nonallophanic Andosols in south Ecuadorian alpine grasslands (páramo). Geomorphology 73: 207-221. doi: 10.1016/j.geomorph.2005.06.012.

Croudace, I.W.; Rindby, A.; Rothwell, R.G. 2006. ITRAX: description and evaluation of a new multi-function X-ray core scanner. In New Techniques in Sediment Core Analysis (Rothwell, R.G.; editor). Geological Society of London: 677-695. London.

Davies, S.M. 2015. Cryptotephras: the revolution in correlation and precision dating. Journal of Quaternary Science 30 (2): 114-130. doi: 10.1002/jqs.2766.

De Fontaine, C.S.; Kaufman, D.S.; Scott Anderson, R.; Werner, A.; Waythomas, C.F.; Brown, T.A. 2007. Late Quaternary distal tephra-fall deposits in lacustrine sediments, Kenai Peninsula, Alaska. Quaternary Research 68: 64-78.
Garrison, J.M.; Davidson, J.P.; Hall, M.; Mothes, P. 2011. Geochemistry and petrology of the most recent deposits from Cotopaxi Volcano, Northern Volcanic Zone, Ecuador. Journal of Petrology 52 (9): 16411678. doi: 10.1093/petrology/egr023.

Geyh, M.A.; Grosjean, M.; Núñez, L.; Schotterer, U. 1999. Radiocarbon reservoir effect and the timing of the lateglacial/early Holocene humid phase in the Atacama Desert (Northern Chile). Quaternary Research 52 (2): 143-153. doi: 10.1006/qres.1999.2060.

Hall, M.L.; Robin, C.; Beate, B.; Mothes, P.; Monzier, M. 1999. Tungurahua Volcano, Ecuador: structure, eruptive history and hazards. Journal of Volcanology and Geothermal Research 91: 1-21.

Hall, M.L.; Samaniego, P.; Le Pennec, J.L.; Johnson, J.B. 2008. Ecuadorian Andes volcanism: A review of Late Pliocene to present activity. Journal of Volcanology and Geothermal Research 176: 1-6.

Harden, C.P. 2006. Human impacts on headwater fluvial systems in the northern and central Andes. Geomorphology 79: 249-263. doi: 10.1016/j.geomorph.2006.06.021

Hidalgo, S.; Monzier, M.; Almeida, E.; Chazot, G.; Eissen, J.P.; van der Plicht, J.; Hall, M.L. 2008. Late Pleistocene and Holocene activity of the AtacazoNinahuilca Volcanic Complex (Ecuador). Journal of Volcanology and Geothermal Research 176: 16-26.

Hopkins, J.L.; Millet, M.-A.; Timm, C.; Wilson, C.J.N.; Leonard, G.S.; Palin, J.M.; Neil, H. 2015. Tools and techniques for developing tephra stratigraphies in lake cores: A case study from the basaltic Auckland Volcanic Field, New Zealand. Quaternary Science Reviews 123: 58-75. doi: 10.1016/j.quascirev.2015.06.014.

Kaufman, D.S.; Jensen, B.J.L.; Reyes, A.V.; Schiff, C.J.; Froese, D.G.; Pearce, N.J.G. 2012. Late Quaternary tephrostratigraphy, Ahklun Mountains, SW Alaska. Journal of Quaternary Science 27: 344-359. doi: 10.1002/jqs.1552.

Kylander, M.E.; Lind, E.M.; Wastegard, S.; Lowemark, L. 2012. Recommendations for using XRF core scanning as a tool in tephrochronology. The Holocene 22: 371375. doi: 10.1177/0959683611423688.

Le Pennec, J.; Jaya, D.; Samaniego, P.; Ramón, P.; Yánez, S.M.; Egred, J.; Plicht, J.; Van Der. 2008. The AD 1300-1700 eruptive periods at Tungurahua volcano, Ecuador, revealed by historical narratives, stratigraphy and radiocarbon dating. Journal of Volcanology and Geothermal Research 176: 70-81.

Le Pennec, J.L.; Ruiz, G.A.; Ramón, P.; Palacios, E.; Mothes, P.; Yepes, H. 2012. Impact of tephra falls on Andean communities: The influences of eruption size and weather conditions during the 1999-2001 activity of 
Tungurahua volcano, Ecuador. Journal of Volcanology and Geothermal Research 217-218: 91-103.

Le Pennec, J.L.; De Saulieu, G.; Samaniego, P.; Jaya, D.; Gailler, L. 2013. A devastating Plinian eruption at Tungurahua volcano reveals Formative occupation at $\sim 1100$ cal BC in central Ecuador. Radiocarbon 55: 1199-1214.

Liu, E.J.; Oliva, M.; Antoniades, D.; Giralt, S.; Granados, I.; Pla-Rabes, S.; Toro, M.; Geyer, A. 2016. Expanding the tephrostratigraphical framework for the South Shetland Islands, Antarctica, by combining compositional and textural tephra characterisation. Sedimentary Geology 340: 49-61. doi: 10.1016/j.sedgeo.2015.08.002.

Lowe, D.J. 2011. Tephrochronology and its application: A review. Quaternary Geochronology 6: 107-153.

Marsh, E.J.; Bruno, M.C.; Fritz, S.C.; Baker, P.; Capriles, J.M.; Hastorf, C.A.; 2018. IntCal, SHCal, or a Mixed Curve? Choosing a ${ }^{14} \mathrm{C}$ Calibration Curve for Archaeological and Paleoenvironmental Records from Tropical South America. Radiocarbon 60: 925-940.

Matthews-Bird, F.; Brooks, S.J.; Gosling, W.D.; Gulliver, P.; Mothes, P.; Montoya, E. 2017. Aquatic community response to volcanic eruptions on the Ecuadorian Andean flank: evidence from the palaeoecological record. Journal of Paleolimnology 58: 437-453.

Monzier, M.; Robin, C.; Samaniego, P.; Hall, M.L.; Cotten, J.; Mothes, P.; Arnaud, N. 1999. Sangay volcano, Ecuador: structural development, present activity and petrology. Journal of Volcanology and Geothermal Research 90: 49-79.

Mosquera, P.V.; Hampel, H.; Vázquez, R.F.; Alonso, M.; Catalán, J. 2017. Abundance and morphometry changes across the high-mountain lake-size gradient in the tropical Andes of Southern Ecuador. Water Resources Research 53: 7269-7280.

Mothes, P.A.; Hall, M.L. 1998. Quilotoa's 800 y BP ash: a valuable stratigraphicmarker unit for the integration period. In Actividad Volcánica y Pueblos Precolombinos en el Ecuador (Mothes, P.; editor), Abya-Yala: 111-138. Quito.

Mothes, P.A.; Hall, M.L. 2008. The Plinian fallout associated with Quilotoa's 800 yr BP eruption, Ecuadorian Andes. Journal of Volcanology and Geothermal Research 176: 56-69.

Paladines, A.; Guzmán, J. 1980. Mapa geológico del Ecuador. Dirección General de Geología y Minas, Hoja Geológica de Cuenca. Escala 1:100,000. Quito.

Peti, L.; Gadd, P.S.; Hopkins, J.L.; Augustinus, P.C. 2019. Itrax $\mu$-XRF core scanning for rapid tephrostratigraphic analysis: a case study from the Auckland Volcanic Field maar lakes. Journal of Quaternary Science: 1-12.
Pyne-O'Donnell, S. 2011. The taphonomy of Last GlacialInterglacial Transition (LGIT) distal volcanic ash in small Scottish lakes. Boreas 40: 131-145

R Core Team. 2019. R: A language and environment for statistical computing. R Foundation for Statistical Computing, Vienna, Austria. https://www.R-project. org/. (last visit 03/09/2020).

Reimer, P.; Bard, E.; Bayliss, A.; Beck, J.W.; Blackwell, P.G.; Bronk Ramsey, C.; Buck, C.E.; Cheng, H.; Edwards, R.L.; Friedrich, M.; Grootes, P.M.; Guilderson, T.P.; Haflidason, H.; Hajdas, I.; Hatté, C.; Heaton, T.J.; Hoffman, D.L.; Hogg, A.G.; Hughen, K.A.; Kaiser, K.F.; Kromer, B.; Manning, S.W.; Niu, M.; Reimer, R.W.; Richards, D.A.; Scott, E.M.; Southon, J.R.; Staff, R.A.; Turney, C.S.M.; Van der Plicht, J. 2013. IntCal13 and Marine13 radiocarbon age calibration curves 0-50,000 years cal. BP. Radiocarbon 55: 1869-1887.

Rodbell, D.T.; Bagnato, S.; Nebolini, J.C.; Seltzer, G.O.; Abbott, M.B. 2002. A Late Glacial-Holocene Tephrochronology for Glacial Lakes in Southern Ecuador. Quaternary Research 57: 343-354.

Rodbell, D.T.; Seltzer, G.O.; Mark, B.G.; Smith, J.A.; Abbott, M.B. 2008. Clastic sediment flux to tropical Andean lakes: records of glaciation and soil erosion. Quaternary Science Reviews 27: 1612-1626.

Salazar, G.; Zhang, Y.L.; Agrios, K.; Szidat, S. 2015. Development of a method for fast and automatic radiocarbon measurement of aerosol samples by online coupling of an elemental analyzer with a MICADAS AMS. Nuclear Instruments and Methods in Physics Research, Section B: Beam Interactions with Materials and Atoms 361: 163-167.

Schneider, T.; Hampel, H.; Mosquera, P.V.; Tylmann, W.; Grosjean, M. 2018. Paleo-ENSO revisited: Ecuadorian Lake Pallcacocha does not reveal a conclusive El Niño signal. Global Planetary Change 168: 54-66.

Schnurrenberger, D.; Russell, J.; Kelts, K. 2003. Classification of lacustrine sediments based on sedimentary components. Journal of Paleolimnology 29: 41-154.

Schultheiss, P.J.; Weaver, P.P.E. 1992. Multi-sensor core logging for science and industry. In Institute of Electric and Electronic Engineering, Oceans 92: 608-613. New York.

Shane, P. 2000. Tephrochronology: A New Zealand case study. Erth Science Reviews 49: 223-259.

Szidat, S.; Salazar, G.A.; Vogel, E.; Battaglia, M.; Wacker, L.; Synal, H.-A.; Türler, A. 2014. ${ }^{14} \mathrm{C}$ analysis and sample preparation at the new Bern laboratory for the analysis of radiocarbon with AMS (LARA). Radiocarbon 56: 561-566. doi: 10.2458/56.17457. 
Trachsel, M.; Telford, R.J. 2017. All age-depth models are wrong, but are getting better. The Holocene 27: 860-869.

Van Colen, W.R.; Mosquera, P.; Vanderstukken, M.; Goiris, K.; Carrasco, M.C.; Decaestecker, E.; Alonso, M.; León-Tamariz, F.; Muylaert, K. 2017. Limnology and trophic status of glacial lakes in the tropical Andes (Cajas National Park, Ecuador). Freshwater Biology 62 (3): 458-473. doi: 10.1111/fwb.12878.

Venzke, E. 2016. Global volcanism program. Volcanoes World, v. 4.8.4. Smithsonian Institution, http://volcano.si.edu/gvp_votw.cfm. (last visit 03/09/2020).
Vogel, H.; Zanchetta, G.; Sulpizio, R.; Wagner, B.; Nowaczyk, N. 2010. A tephrostratigraphic record for the last glacial-interglacial cycle from Lake Ohrid, Albania and Macedonia. Journal of Quaternary Science 25: 320-338.

Zawalna-geer, A.; Lindsay, J.A.N.M.; Davies, S.; Augustinus, P.; Davies, S. 2016. Extracting a primary Holocene crytoptephra record from Pupuke maar sediments, Auckland, New Zealand. Journal of Quaternary Science 31 (5): 442-457. doi: 10.1002/ jqs.2866.

Manuscript received: September 29, 2019; revised/accepted: February 3, 2020; available online: May 29, 2020. 